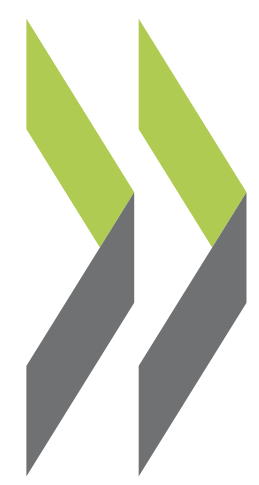

OECD Economics Department Working Papers No. 697

Labour Market Flexibility in Estonia: What more Can Zuzana Brixiova be Done? 


\section{Unclassified}

ECO/WKP(2009)38

Organisation de Coopération et de Développement Économiques

Organisation for Economic Co-operation and Development

ECONOMICS DEPARTMENT

English - Or. English

LABOUR MARKET FLEXIBILITY IN ESTONIA: WHAT MORE CAN BE DONE?

ECONOMICS DEPARTMENT WORKING PAPERS No. 697

by Zuzana Brixiova

All Economics Department Working Papers are available through OECD's internet website at www.oecd.orh/eco/working_papers 
Abstract/Résumé

\section{Labour market flexibility in Estonia: what more can be done?}

In mid-2008, high employment and low unemployment rates characterised the Estonian labour market in comparison with the average of the EU15 countries. While aggregate outcomes improved during 2000-07, large inequalities persisted across regions, ethnic groups, and workers with different skill levels. As Estonia entered recession in 2008, the unemployment rate almost doubled between the 2 nd and the 4th quarter, and is expected to rise further in 2009 and 2010.

More flexible labour markets will be a key adjustment mechanism during the recession as well as in the medium term if Estonia is to become a knowledge-based economy. Given the currency board arrangement and low synchronisation with the euro area, flexibility is also needed to cushion asymmetric shocks. In December 2008, parliament adopted the new Employment Contract Act, deregulating employment protection while increasing income security of the unemployed. This paper discusses options for removing the remaining barriers that impede worker reallocation across jobs, sectors, and regions into more productive activities.

This Working Paper relates to the 2009 OECD Economic Survey of Estonia (www.oecd.org/eco/surveys/estonia). It is only available in PDF format.

JEL Classification: J08, J64, E24.

Keywords: Labour market policies; flexibility; Estonia.

$* * * * *$

\section{La flexibilité du marché du travail en Estonie : comment l’améliorer ?}

Au milieu de 2008, le marché du travail estonien se caractérisait par un taux élevé d'emploi et un faible taux de chômage par comparaison avec la moyenne de l'UE15. De fortes inégalités persistaient entre régions, groupes ethniques et travailleurs de niveaux différents de qualification. Lorsque l'Estonie est entrée en récession en 2008, le taux de chômage a presque doublé entre le $2^{\text {ème }}$ et le $4^{\text {ème }}$ trimestre, et il devrait encore augmenter en 2009 et 2010.

Une plus grande flexibilité du marché du travail constituera un mécanisme essentiel d'ajustement durant la récession et à moyen terme dans la perspective d'une économie fondée sur le savoir. En décembre 2008, le parlement a adopté la loi sur l'emploi, qui a déréglemente la protection de l'emploi tout en renforçant la sécurité du revenu pour les chômeurs. Ce document a pour thème l'élimination des obstacles résiduels au redéploiement des travailleurs entre emplois, secteurs et régions, au profit des activités plus productives.

Ce Document de travail se rapporte à l'Étude économique de l'OCDE de l'Estonie 2009 (www.oecd.org/eco/etudes/estonie). Il est uniquement disponible en format PDF.

Classification JEL : J08 ; J64 ; E24.

Mots clés : Politiques du marché du travail ; flexibilité ; Estonie.

\section{Copyright OECD, 2009}

Application for permission to reproduce or translate all, or part of, this material should be made to : Head of Publications Service, OECD, 2 rue André-Pascal, 75775 Paris Cedex 16, France. 


\section{TABLE OF CONTENTS}

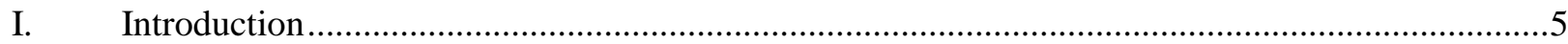

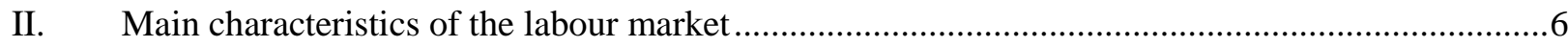

Driven by fast growth, overall labour market outcomes markedly improved during 2000-07 ..............6

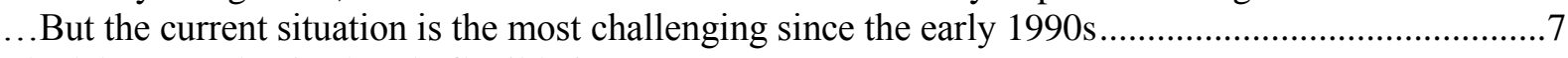

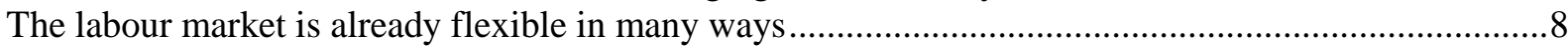

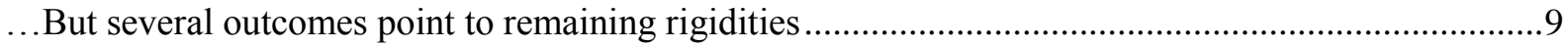

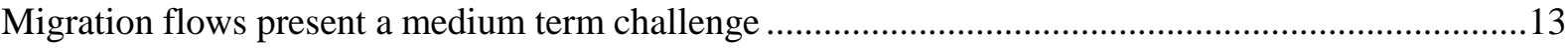

III. Institutional landscape and reforms adopted in 2008 ...........................................................

The 2008 Employment Contract Act makes employment protection lighter .........................................14

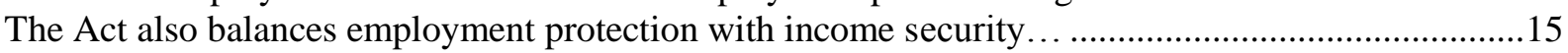

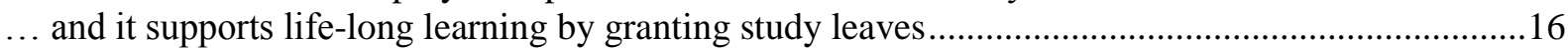

Some measures to ease integration of foreign workers were also adopted ...........................................16

...But other key labour market institutions remain unchanged ......................................................17

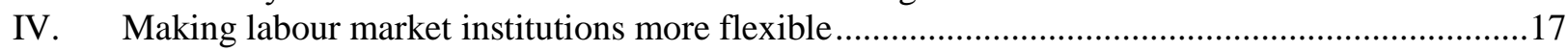

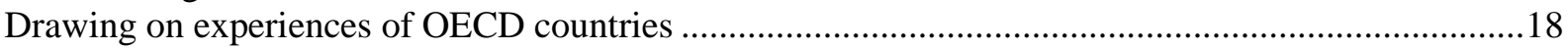

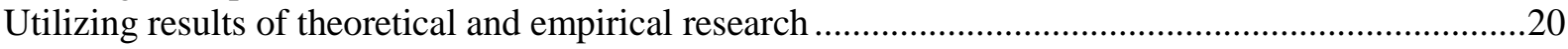

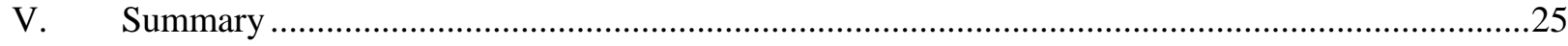

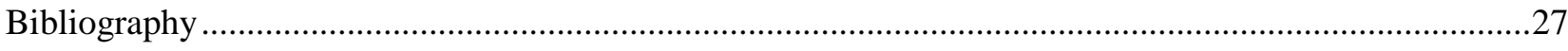

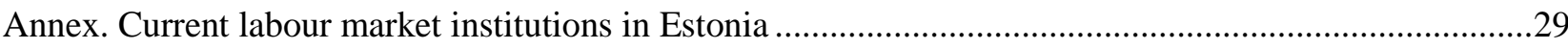

\section{Tables}

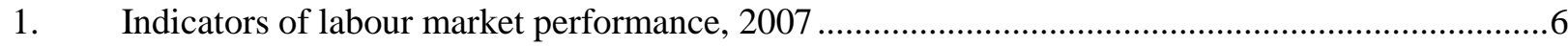

2. Average flows between three labour market States ................................................................

3. Unemployment rates by citizenship and language skills, 2003-07 .......................................10

4. Employment protection legislation in central European countries (2003) and in Estonia .............15

5. Participation in life-long learning, by education attainment .......................................................16

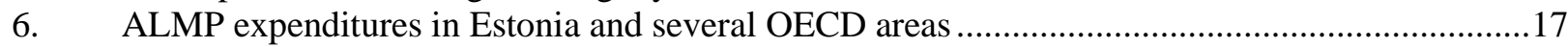

7. Comparative statics in the job search-matching model...............................................................

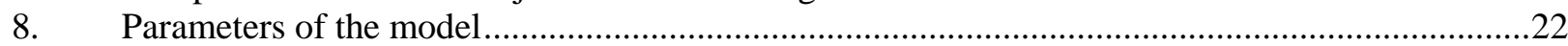

\section{Figures}

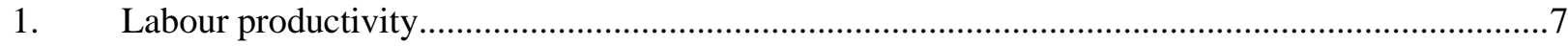

2. Real GDP, wages and unemployment rate, 2001-08 …..........................................................

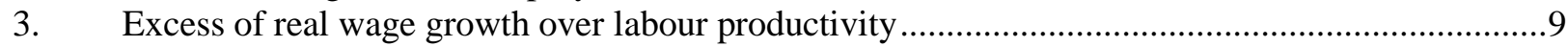

4. Average unemfployment rates during 1993-2007, by regions ...................................................10

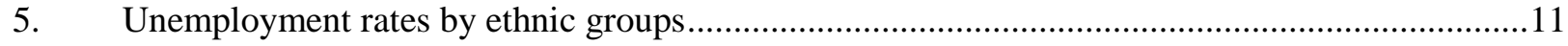

6. Employment rates of low-skilled workers in selected EU countries.......................................12

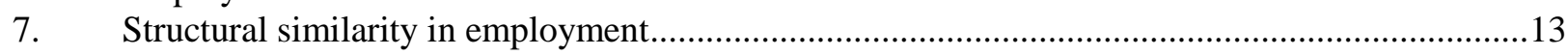

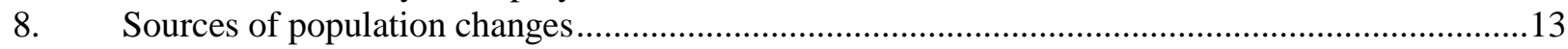

9. Impact of mandatory participation in labour market policies on search and unemployment .........22 


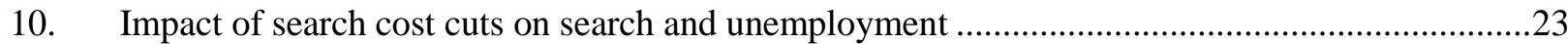

11. Impact of minimum wage increase on search, unemployment and vacancies .............................23

12. Impact of social security tax on vacancies and unemployment ................................................24

\section{Boxes}

1. Migration in Estonia - Current situation and future challenges..............................................14

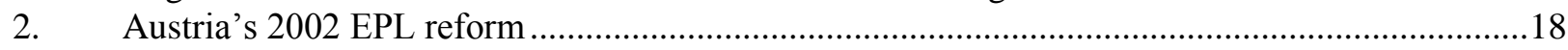

3. Policy recommendations for increasing flexibility of the labour market.....................................25 
ECO/WKP(2009)38

\title{
LABOUR MARKET FLEXIBILITY IN ESTONIA: WHAT MORE CAN BE DONE?
}

\author{
by Zuzana Brixiova ${ }^{1}$
}

\section{Introduction}

Following a deterioration related to transition to a market economy and the Russian crisis, the labour market outcomes in Estonia improved markedly by end-2007: the employment rate exceeded the EU15 average, unemployment rates were low, and the participation rates increased. While aggregate outcomes improved, large inequalities persisted among regions, ethnic groups, and workers with different skill levels.

As Estonia entered recession in 2008, the unemployment rate almost doubled between the 2 nd and the 4th quarter, and is expected to rise further in 2009 and 2010. Given the current downturn and the overexpansion of non-tradables, a pressing issue for policymakers is how to support reallocation of workers across jobs, sectors, and regions to more productive activities, while considering associated social and fiscal costs. In this context, flexibility of the labour market, together with job creation incentives, will be key. Since Estonia opted for currency board pegged to euro, labour market flexibility is also a key adjustment mechanism in case of asymmetric shocks relative to the euro area.

This paper summarizes trends, institutions and recent reforms in Estonia, including the recent deregulation of employment protection and enhancement of unemployment insurance. Drawing on experiences of successful OECD reformers, the paper suggests that the labour market could become even more flexible if: (i) raises in unemployment benefits were conditional on participation of the unemployed in active labour market policies including job search programmes; (ii) increases of the real public sector and minimum wages were kept in line with productivity growth; and (iii) the employers' social security contributions were reduced, especially for low-wages workers. While the recession will dampen the positive impact of labour market programmes, strengthening search incentives today should nevertheless improve medium-term outcomes and also ease the recovery.

A simulation exercise based on the labour market matching model with participation in job search programmes of Van Ours (2007) illustrates quantitatively the impact of several reforms on the search effort of the unemployed and job creation by firms. The model results confirm that i) linking unemployment benefits to participation in job search programmes improves workers' incentives to search for jobs and could reduce unemployment if accompanied by effective job creation incentives; ii) in contrast, lowering

1. Most of the material in this paper was originally prepared for the OECD Economic Survey of Estonia, which was considered by the Economic and Development Review Committee in January 2009 and published in April 2009. The author is especially thankful to Andreas Wörgötter, Laura Vartia and Isabell Koske for comments and discussions. She also thanks Andrew Dean, Balázs Égert, Bob Ford, Katrin Höövelson, Baudouin Lamine, and Stefano Scarpetta for their insights at different stages of this draft, Margaret Morgan for statistical assistance, and Josiane Gutierrez for editing. Thanks go to Egle Käärats from the Ministry of Social Affairs for discussing the labour market institutions and reforms, and to Ülle Pettai and Siim Krusell from the Statistics Estonia for providing data. E-mail address: zuzana.brixiova@oecd.org. 
minimum wages hampers incentives of the low-wage unemployed to search for jobs, but makes firms more willing to hire; iii) cuts in firms' social security contributions can raise firms' incentives to hire.

The paper is organized as follows. Section II provides an overview of the recent labour market trends; Section III describes the key reforms of labour market institutions undertaken in 2008; Section IV summarizes reform experiences of the OECD countries, supported by the policy simulations utilizing a search-matching model; and Section V concludes.

\section{Main characteristics of the labour market}

\section{Driven by fast growth, overall labour market outcomes markedly improved during 2000-07}

\section{Unemployment dropped while employment and participation rates increased}

During 2000-07, Estonia's real GDP growth was one of the highest among the emerging market economies and, until 2005, inflation was low. As a result of rapid growth, Estonia achieved a high rate of convergence to income levels of the EU15. The labour market outcomes also improved markedly: the unemployment rate dropped to its lowest point in 16 years in mid-2008, and the employment rate increased, including for workers of ages 55-64 and women. ${ }^{2}$ Labour force participation also rose, as different groups of workers were able to seize new opportunities in a booming economy (Table 1).

Table 1. Indicators of labour market performance, 2007

\begin{tabular}{|c|c|c|c|c|c|}
\hline & \multirow[b]{2}{*}{$\begin{array}{c}\text { Unemployment } \\
\text { rates } \\
(\% \text { of LF })\end{array}$} & \multirow[b]{2}{*}{$\begin{array}{c}\text { Activity rates (\% of } \\
\text { population } \\
\text { aged } 15-64)\end{array}$} & \multicolumn{3}{|c|}{ Employment rates (\% of population) } \\
\hline & & & Ages 15-64 & Ages 15-24 & Ages $55-64$ \\
\hline Estonia & 4.7 & 72.9 & 69.4 & 34.5 & 60.0 \\
\hline Czech Republic & 5.3 & 69.9 & 66.1 & 28.5 & 46.0 \\
\hline Hungary & 7.4 & 61.9 & 57.3 & 21.0 & 33.1 \\
\hline Latvia & 6.0 & 72.8 & 68.3 & 38.4 & 57.7 \\
\hline Lithuania & 4.3 & 67.9 & 64.9 & 25.2 & 53.4 \\
\hline Poland & 9.6 & 63.2 & 57.0 & 25.8 & 29.7 \\
\hline Slovak Republic & 11.1 & 68.3 & 60.7 & 27.6 & 35.6 \\
\hline Slovenia & 4.8 & 71.3 & 67.8 & 37.6 & 33.5 \\
\hline EU15 & 7.0 & 72.0 & 66.9 & 40.8 & 46.6 \\
\hline
\end{tabular}

Source: European Commission (2008).

\section{Labour productivity grew rapidly}

During 2000-07 Estonia's labour productivity growth was markedly higher than in the EU15, the OECD central European members (Figure 1), and even exceeded that of Latvia and Lithuania, countries which also had high GDP growth rates. At sector levels, market services and manufacturing were the main drivers, while within services financial intermediation played a key role. Nevertheless, the level of labour productivity amounted to only about $62 \%$ of the EU27 average at end-2007. ${ }^{3}$

2. The employment rate rose by 10 percentage points to $69 \%$ of working-age population in $2000-07$.

3. Chapters 1, 4, and 5 in OECD (2009) discuss drivers of the labour productivity growth further. 


\section{Figure 1. Labour productivity}

Index, $2000=100$

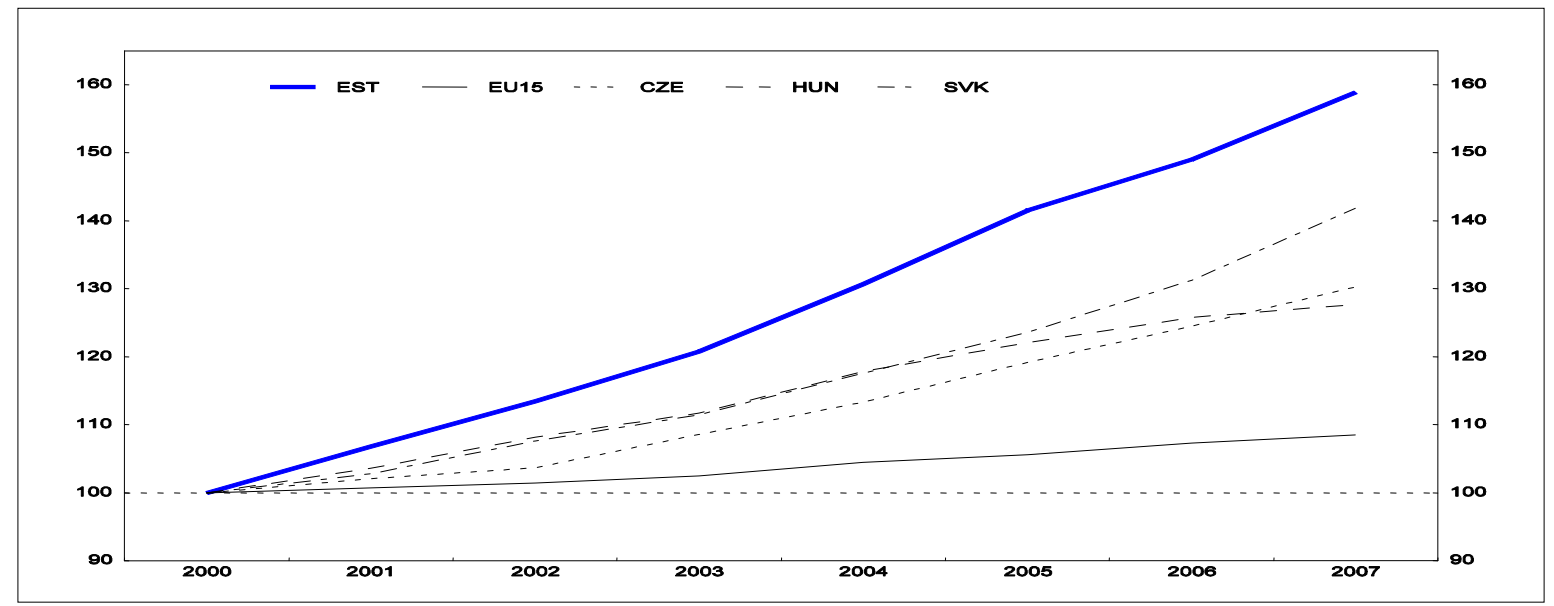

Source: European Commission, Employment in Europe (2008).

\section{...but the current situation is the most challenging since the early 1990s}

The Estonian economy is currently experiencing a hard landing, mostly unwinding a loan-financed over-expansion of non-tradable sectors. Growth slowed already in mid-2007, due to subdued domestic demand and foreign-financed credit, and collapsed in 2008. Labour markets reacted with a lag unemployment increased rapidly only in the second half of 2008 while real wages stagnated (Figure 2). Unemployment is projected to rise further in 2009 and 2010 (OECD, 2009). More flexible labour markets will be crucial to achieve a timely recovery with rebalanced growth.

Figure 2. Real GDP, wages and unemployment rate, 2001-08

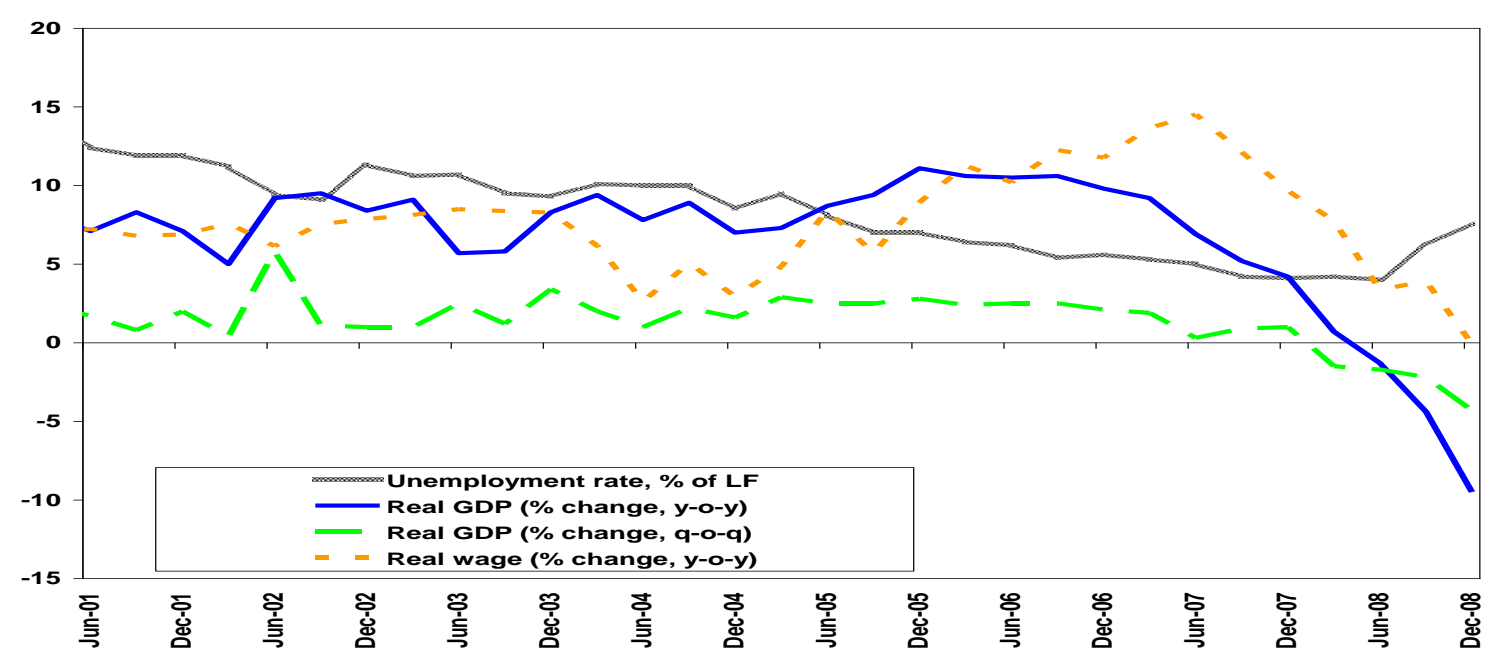

Source: Statistics Estonia. 


\section{The labour market is already flexible in many ways}

Labour market flexibility reflects how quickly the labour markets adjust to shocks to achieve optimal (or at least improved) allocation of resources (Pissarides, 1997). Four elements are typically discussed: i) numerical flexibility, i.e. employment in individual firms; ii) working time, i.e. the working hours; iii) functional flexibility, i.e. the scope for transferring employees between job functions; and $i v$ ) wage, i.e. the rate at which nominal and real wages respond to changes in supply and demand (Eamets and Paas, 2007). Sections below focus on the numerical and wage aspects.

\section{Worker flows}

Estonia's labour market in the mid-1990s was characterized by higher worker and job flows than in most other transition economies (Vodopivec, 2000). Over the past ten years, the dynamism in the labour market provided increasing opportunities of exiting unemployment, while employment turnover slowed (Table 2). ${ }^{4}$ The speed at which workers will be able to move to new activities during the downturn will indicate whether the recent lower employment turnover stemmed mainly from the improved economy or also from rigid or better enforced institutions.

Table 2. Average flows between three labour market States

\begin{tabular}{lccc}
\hline & $1997 / 98-1999 / 00$ & $2000 / 01-2003 / 04$ & $2004 / 05-2006 / 07$ \\
\cline { 2 - 3 } EE & 91.3 & 92.3 & 94.6 \\
EU & 4.5 & 3.5 & 1.8 \\
EO & 4.2 & 4.2 & 3.6 \\
UE & 31.1 & 33.2 & 41.0 \\
UU & 61.8 & 53.0 & 49.4 \\
UO & 7.1 & 13.8 & 9.6 \\
OE & 5.6 & 5.4 & 7.1 \\
OU & 2.4 & 3.2 & 2.1 \\
OO & 92.0 & 91.4 & 90.8 \\
\hline
\end{tabular}

Notes: E-employment; U—unemployment; O—non-participation; EE—staying in employment; EU—flow from employment to unemployment; EO-flow from employment to inactivity, etc.

Source: Statistics Estonia and author's calculations.

Wage flexibility

Masso et al. (2007) measured how quickly wages reacted to shocks and found that at the end of the 1990s nominal wages were more flexible in Estonia than in Latvia and Lithuania. Using macroeconomic data on wages, productivity, inflation, and unemployment, Babecky (2008) demonstrated that real wages moved closely with labour productivity during 1995-2004, consistently with studies of Room (2008) and others.

A key factor contributing to the wage flexibility in Estonia is a widespread usage of performance-related bonuses. The 2007 survey of private firms in industry, constructions, services, and trade revealed that about two thirds of firms use bonuses, and their share in the wage bills ranged from $14 \%$ in industry to $23 \%$ in trade (Dabusinskas and Room, 2008).

4. In the late 1990s, unemployment in Latvia and Lithuania was more dynamic than in Estonia because of many workers going into inactivity (Masso et al., 2007). In Estonia significant movement went on within the employment, as workers changed jobs frequently (Statistics Estonia). 


\section{...but several outcomes point to remaining rigidities}

In recent years labour and skill shortages led to wage increases above productivity growth

During 2005-07, skill shortages and mismatches led to rapid real wage increases above labour productivity growth. ${ }^{5}$ According to the Estonian Institute for Economic Research, skill shortages emerged across a number of sectors, including construction and services, and were reflected in private wages (Figure 3). Public sector wages also increased rapidly, especially in health and social services.

\section{Figure 3. Excess of real wage growth over labour productivity}

Average, percentage points

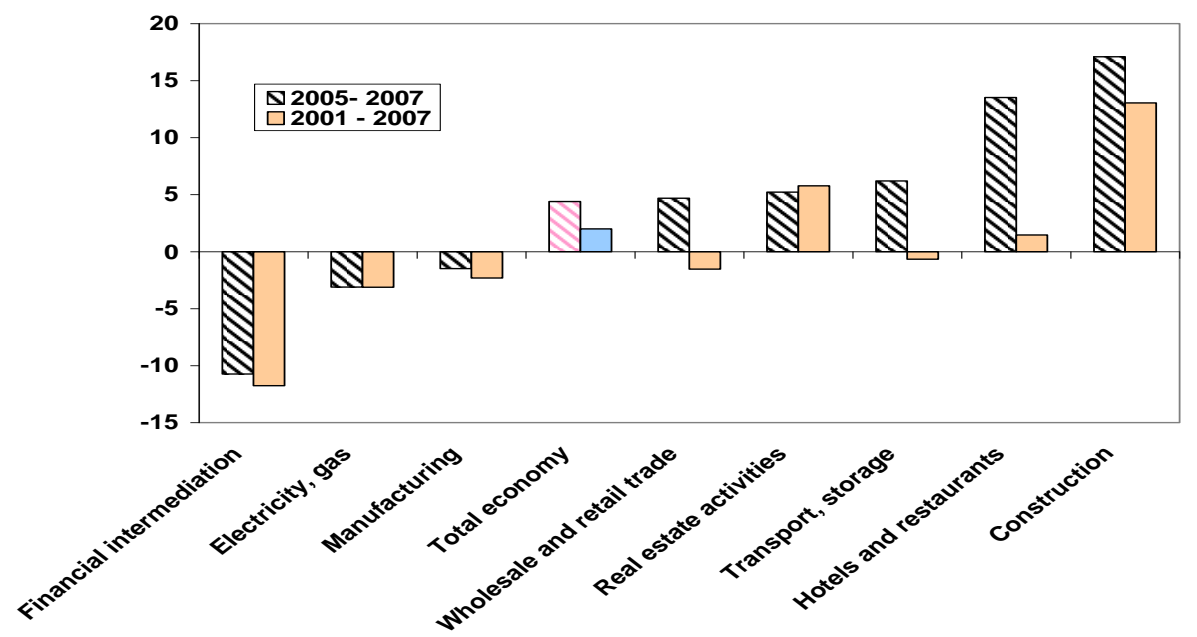

Source: Statistics Estonia and author's calculations.

\section{Regional disparities in employment and unemployment persisted}

Disparities in employment rates among regions widened and several counties became caught in a "low employment trap", with employment rates below $90 \%$ of the national average. ${ }^{6}$ These regional differences have been persistent -- the three counties with the lowest rates in 2000 were still the worst performing in 2007, indicating that policies have not adequately addressed local constraints.

As in more advanced EU countries, differences in production structures and human capital explain much of the employment gap between various areas. Areas with high employment are characterized by relatively large shares of output concentrated in high-tech sectors and knowledge-intensive services, and possess a highly-skilled labour force. ${ }^{7}$ In turn, the areas with poor outcomes had a high share of employment in agriculture and a below average share of labour with tertiary education.

5. The low employment of low-skilled workers during this period coincided with skill shortages in high-tech sectors and knowledge-intensive services.

6. Estonia is divided into 5 regions and 15 counties.

7. In 2007 services accounted for $70 \%$ of employment in Harju and Tartu counties; about $40 \%$ of their workers had tertiary education, in contrast with the national averages of 60 and $34 \%$, respectively. 
While during 2000-07 the unemployment rates declined in all regions and counties, the North-eastern region bordering with Russia, where many of the ethnic Russians reside, had persistently the highest unemployment (Figure 4). Even with the national unemployment rate of $4.7 \%$ at the end of 2007, it was still $9 \%$ in this region. The rise in unemployment at the end of 2008 was again steepest in Ida Viru county -- to almost $12 \%$ of the labour force, in contrast to $5-6 \%$ in the rest of the country.

Figure 4. Average unemployment rates by regions, June 2000 - December 2008 Percent of labour force

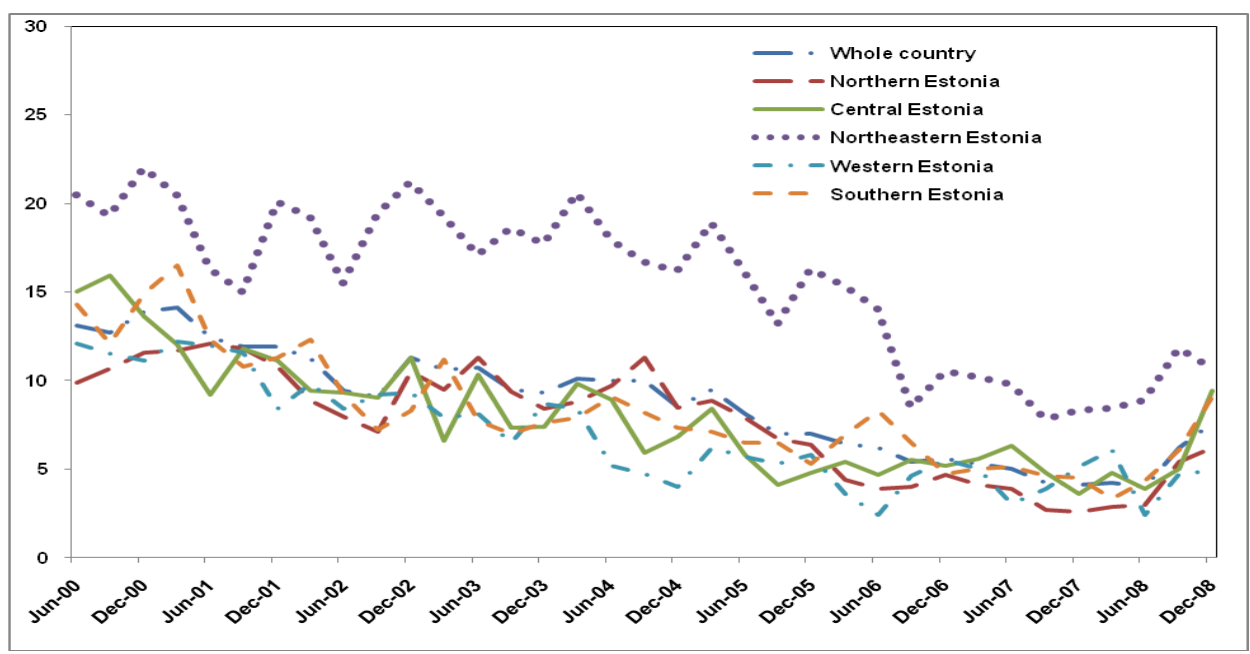

Source: Statistics Estonia.

The poor labour market outcomes in the North-eastern region are partly due to its industrial heritage, as the region was heavily hit by restructuring of the large-scale enterprises. The geographical proximity of less-developed regions in Russia is another factor, since the labour market performance of regions is linked to the surrounding areas, even if those are located in different countries (OECD, 2005a). ${ }^{8}$ Finally, private sector development has been slow and skill mismatch emerged between workers laid off from state owned enterprises and demands of the new firms. ${ }^{9}$

Table 3. Unemployment rates by citizenship and language skills, 2003-07 In percent of the relevant labour force

\begin{tabular}{lccccc}
\hline & 2003 & 2004 & 2005 & 2006 & 2007 \\
\cline { 2 - 6 } & 7.3 & 6.4 & 5.3 & 4.0 & 3.9 \\
Ethnic Estonians & & & & & \\
Ethnic non-Estonians & 9.4 & 8.6 & 6.5 & 4.9 & 3.9 \\
with citizenship, with Estonian language skills & 15.8 & 12.4 & 7.5 & 8.6 & 5.2 \\
without citizenship, with Estonian language skills & 15.0 & 8.0 \\
with citizenship, without Estonian language skills & 17.3 & 17.5 & 23.8 & 15.0 & \\
without citizenship and Estonian language skills & 20.9 & 20.7 & 20.3 & 12.9 & 11.0 \\
\hline
\end{tabular}

Source: Statistics Estonia.

8. In the NMS regions at the Western borders - and a better access to Western markets - attract large inflows of foreign capital, which raises their potential to generate income and jobs (Iara et al., 2009).

9. For example, downsizing of Krenholm, one of the largest textile companies in Estonia, has been complicated as most of the employees are women aged 50 years or more who: $i$ ) do not speak Estonian; ii) cannot easily move; and iii) have only basic or specialised high school education. 


\section{Labour market outcomes of ethnic non-Estonians lag behind}

Employment and especially unemployment rates have differed between ethnic Estonians and nonEstonians, mostly Russians (Figure 5). ${ }^{10}$ The differences in youth (ages 15-24 years) and long-term unemployment rates are particularly striking. Unemployment differed markedly depending on the knowledge of the Estonian language (less than on citizenship), underscoring the importance of access to language training for all Estonian residents (Table 3). ${ }^{11}$

Figure 5. Unemployment rates by ethnic groups, 1997 - 2008

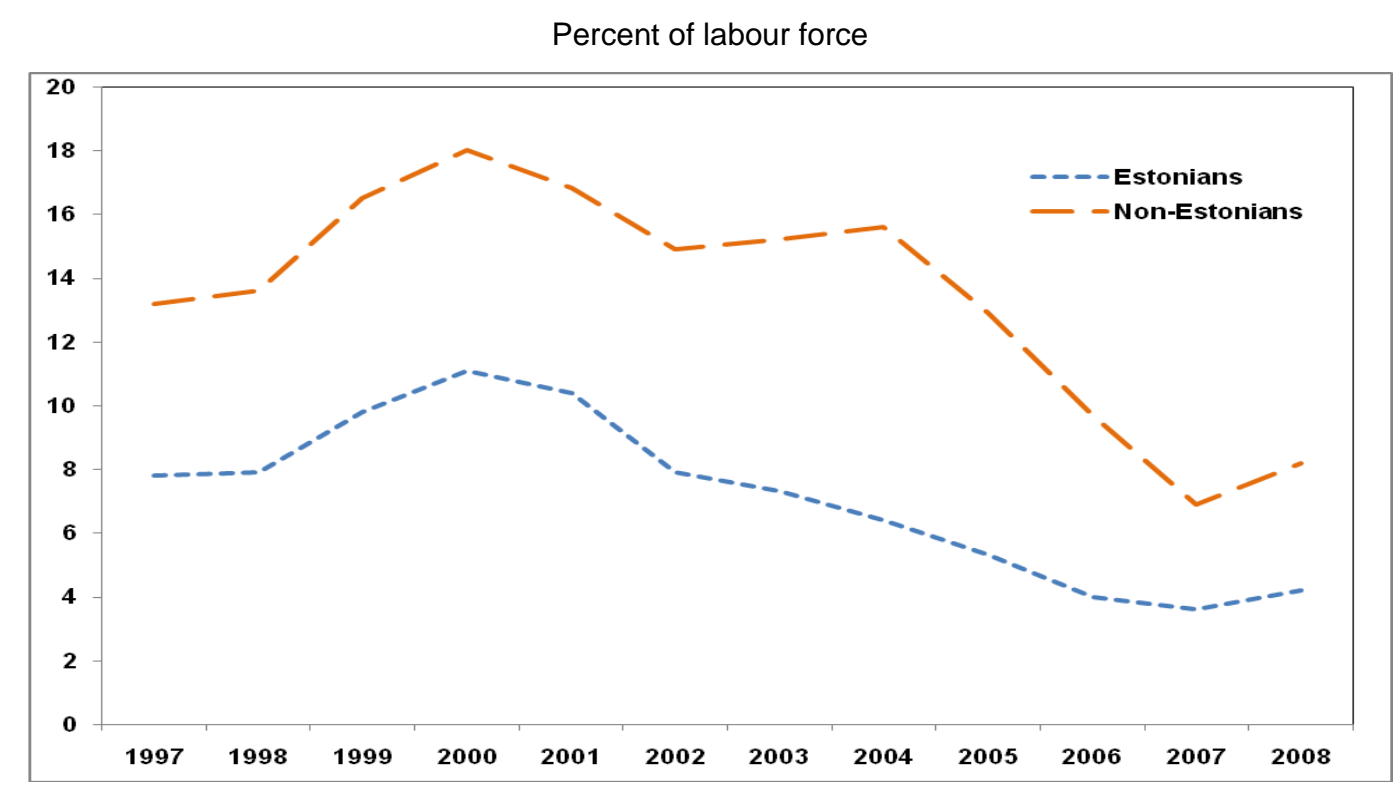

Source: Statistics Estonia.

The gap between the average wages of ethnic Estonians and non-Estonians remains wide. Leping and Toomet (2008) found that an ethnic non-Estonian with characteristics similar to an ethnic Estonian earned on average 10-15\% less in the mid-2000s. A substantial part of this gap cannot be explained by factors causing differences in productivity, such as human capital. ${ }^{12}$ About 2-4 percentage points of the gap are explained by a lack of Estonian language skills. The authors found entry barriers to the labour market and separate social networks to be additional factors.

\section{Low-skilled workers fared particularly poorly}

While Estonia's employment rates of workers with tertiary education were comparable to those of the EU15 (80\%), rates for low-skilled were much lower (Figure 6). ${ }^{13}$ Low skilled workers also experienced

10. Non-Estonian ethnic minorities comprise a significant portion (32\% of the population). The vast majority of them are ethnic Russians (265 of population) or other Russian-speakers.

11. The Law on Citizenship makes knowledge of Estonian necessary for acquiring Estonian citizenship. In 2005, 71\% of ethnic Russians with Estonian citizenship had advanced Estonian language skills in contrast with 5\% of ethnic Russians with Russian citizenship (Karu and Roosaar, 2006).

12. Kroncke and Smith (1999) found that the unexplained wage gap was close to zero in the late 1980s, it has risen till about $15 \%$ in the late 1990 s, peaked at $25 \%$ in 2003 , before declining to $10 \%$ in 2005 .

13. However, Estonia's employment rates of low-skilled workers exceeded those of the OECD Central European members, discussed in Brixiova, Li and Yousef (2009). 
high unemployment rates and constituted a disproportionate share among the long-term unemployed. Experience of the OECD countries suggests that a high tax wedge and the rapid growth of minimum wages in recent years contributed to this situation (Bassanini and Duval, 2006).

Figure 6. Employment rates of low-skilled workers in selected EU countries Percent of working age population

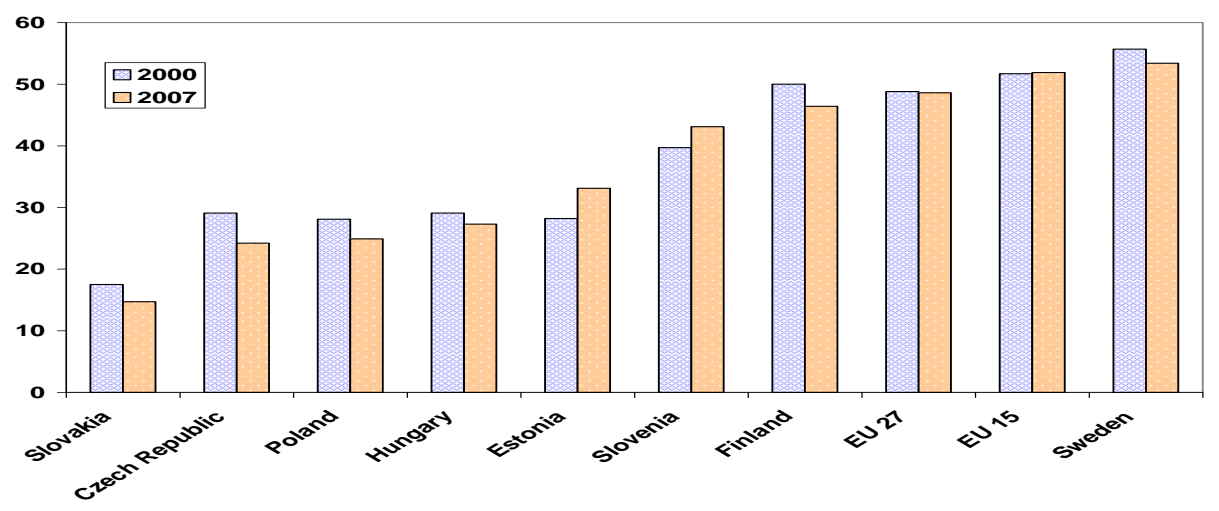

Source: Eurostat.

The share of employment in knowledge and high-tech intensive sectors remains low

As other transition countries, Estonia experienced large sectoral shifts in employment during the 1990s, with adjustment toward the EU15 structure. During 2004-07 the sectoral reallocation was higher than among regional peers, the Czech Republic and Slovenia (7\% vs. 2-3\%). ${ }^{14}$ These shifts were driven by the transition to a market economy, the Russian crisis, and the EU accession.

During 2000-07, new jobs in Estonia were created mostly in construction, manufacturing, and trade. The share of employment in construction increased from 7 to $12 \%$ and approached that of Spain (13\%), as also confirmed by the index of employment similarity between Estonia and the EU15 (Figure 7). ${ }^{15}$ In contrast, in the EU15, and especially in Finland and Sweden, new jobs were created mostly in business services, health, and education. Estonia has thus relatively low employment in high-tech and knowledge intensive sectors, despite high rates of tertiary graduates. ${ }^{16}$

14. Index of labour mobility, defined as $\sum\left|\frac{N_{i}}{N}(2007)-\frac{N_{i}}{N}(2004)\right| / 2$, where $N_{i}$ is employment in sector $i$ and $N$ is total employment.

15. Defined as $I_{i j}=\sum_{k} \frac{N_{i k} / N_{i}}{N_{j k} / N_{j}}$, where $N_{i k}$ is employment in sector $k$ in country $i$ and $N_{i}$ is total employment in country $i$.

16. $27 \%$ of population had tertiary education in 2007 vs. $22 \%$ in the EU15 (Iara et al., 2009). 
Figure 7. Structural similarity in employment

Employment share in Estonia relative to that in EU15

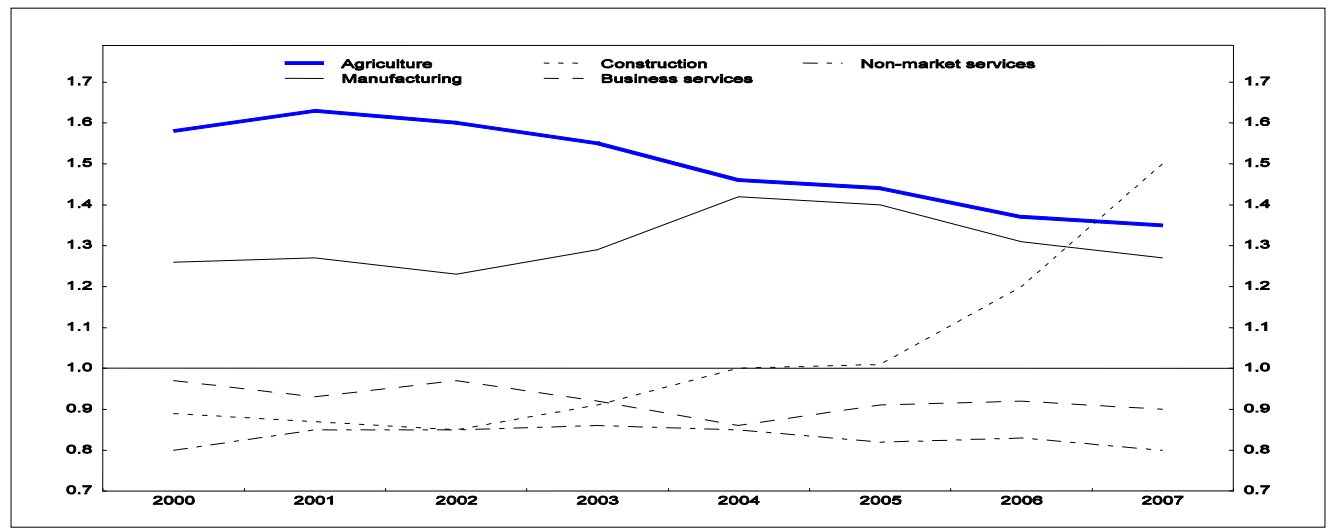

Note: A ratio of less than one indicates a lower share of employment in a sector in Estonia than in EU15. Source: Author's calculations based on data from Eurostat and Statistics Estonia.

\section{Migration flows present a medium term challenge}

During 1991-2008, Estonia's population shrank by 15\%, as ethnic Russians, Ukrainians and Belarusians returned to their home countries in the 1990s. In the 2000s ethnic Estonians emigrated as well, mostly for economic reasons to the OECD countries. Natural attrition due to low birth rates has contributed to population decline (Figure 8), which was accompanied by aging population, with its composition now close to the EU15. At the same time, immigration has grown over the years with the rising living standards, and in 2007 Estonia experienced very small net immigration (Box 1).

Figure 8. Migration and population changes

Changes as $\%$ of total population

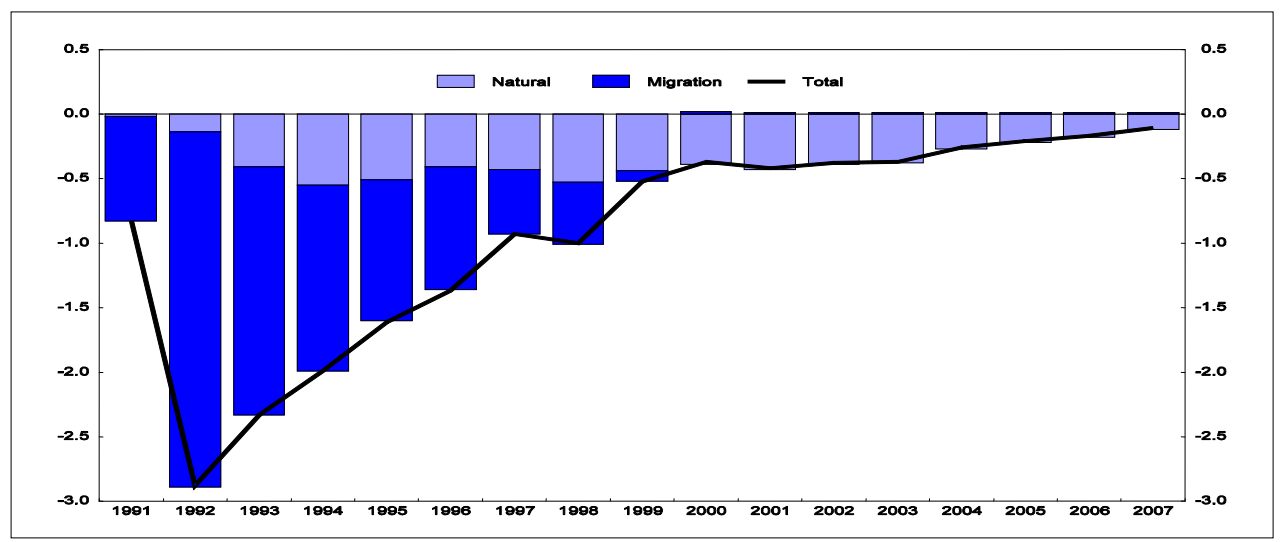

Note: Natural change is births minus deaths during a year. The graph shows this as a percentage of the population at the end of the year. Migration is the residual of total and natural change. Source: OECD calculations based on data from Statistics Estonia. 


\section{Box 1. Migration in Estonia - Current situation and future challenges}

\section{Who are the Estonian migrants?}

During 2000-07, 26518 persons, or $2 \%$ of the Estonian population, emigrated (Statistics Estonia), decreasing population by about $0.2 \%$ a year. During this period, the main countries of destination were: i) Finland (17 165 emigrants); ii) Russia (3 601 emigrants); and iii) Germany (1 271 persons). The typical Estonian emigrant in 2007 was young (below 35 years), female (54\%), ethnic Estonian (81\%), and with secondary or basic education, confirming poor employment prospects for low-skilled workers in Estonia.

Emigration to the EU countries tends to be temporary, associated with short periods of study and work abroad. The motivation and composition of emigrants to the CIS countries is different from this general trend: the average age of emigrants to the CIS countries is 42 years, with the ethnic Russians, Ukrainians, and Belarusians comprising $91 \%$. While emigration from Estonia has generally increased, in particular after joining the EU, emigration to the CIS countries has decreased markedly after 2000 (Statistics Estonia, 2009).

During 2000-07, 10326 people immigrated to Estonia, i.e. $0.1 \%$ of the Estonian population a year; $43 \%$ were returning migrants. A large share of immigrants who came to Estonia for work are employed in services as managers, professionals (mostly from the EU15 countries) or technicians (mostly from the CIS).

\section{Emigration as a possible buffer during the current downturn}

A study by the Bank of Estonia (2008) states that Estonia could become a net emigration country again during the current downturn. While economic conditions abroad have significantly deteriorated, the removal of remaining restrictions on free movement of labour in the EU could provide an extra stimulus. Still, the focus of the Estonian policymakers should be on job creation at home and adequate security for the most vulnerable.

\section{Medium term perspective -- Estonia as a net immigration country}

Taking a historical perspective, Münz (2008) suggests that most new EU members will likely become net immigration countries in the future, as western European countries have all become destinations for international migrants and asylum seekers during the past 60 years. Estonia was already a net immigration country in 2007.

\section{Institutional landscape and reforms adopted in $\mathbf{2 0 0 8}$}

Policy-oriented research on flexibility tends to assess to what extent institutions and regulations impede labour market adjustment (Svejnar et al., 2003). Accordingly, this section briefly outlines the existing labour market institutions and reforms under way.

\section{The 2008 Employment Contract Act makes employment protection lighter}

Estonia's current EPL, adopted in 1992, is more rigid than in Central European countries and the OECD average (Table 4). The rigidity stems mainly from regulation of regular contracts, notably from long notice periods for workers with short tenure; strict definition of unfair dismissal; and the right to re-employment or high compensation in cases of unfair dismissal. Rules on collective dismissals include obligations to inform the third party. However, Eamets and Masso (2005) found that in practice the enterprises had mostly disregarded these strict EPL regulations in the early 2000s. 
ECO/WKP(2009)38

Table 4. Employment protection legislation in central European countries (2003) and in Estonia

(June 2008): range 0-6, with higher value indicating greater protection

\begin{tabular}{lcccc}
\hline & $\begin{array}{c}\text { Regular } \\
\text { employment }\end{array}$ & $\begin{array}{c}\text { Temporary } \\
\text { employment }\end{array}$ & $\begin{array}{c}\text { Collective } \\
\text { dismissals }\end{array}$ & Overall \\
\cline { 2 - 5 } Estonia & $\mathbf{2 . 5 2}$ & $\mathbf{1 . 7 5}$ & $\mathbf{3 . 2 5}$ & $\mathbf{2 . 3 2}$ \\
OECD average & 2.14 & 1.78 & 3.06 & 2.14 \\
Poland & 2.23 & 1.25 & 4.13 & 2.14 \\
Czech Republic & 3.31 & 0.50 & 2.13 & 1.94 \\
Hungary & 1.92 & 1.13 & 2.88 & 1.75 \\
Slovak Republic & 2.30 & 0.38 & 3.80 & 1.70 \\
\hline
\end{tabular}

Source: OECD Employment Outlook 2004; Estonia: Country response to OECD EPL questionnaire.

In December 2008, parliament adopted the new Employment Contract Act, effective in July 2009. In addition to introducing comprehensive deregulation to the EPL, the Act reduces bureaucracy, including merging the Labour Market Board and the Unemployment Insurance Board. ${ }^{17}$

While the EPL reforms in several OECD countries focused on temporary contracts, the Estonian Act tackles the regular contracts. ${ }^{18}$ It reduces the notice period for redundancy to 15-90 working days, depending on the length of employment. Severance payments are also cut, and the cost is shared between the employer and the Unemployment Insurance Fund. By easing dismissals and hiring, the EPL deregulation is expected to increase mobility (OECD, 2004). ${ }^{19}$ The newly adopted EPL changes should be fully implemented as stipulated in the Act.

\section{The Act also balances employment protection with income security...}

Discussions between the government, employers' representatives and trade unions on the changes in the Act lasted several years, mainly because of social partners' concern about reduced employees' security due to a lighter EPL. As a compromise, the adopted Act raises the initial unemployment benefit replacement rate and eases the eligibility for unemployment insurance. ${ }^{20}$ The Act also moves back the period of collecting unemployment benefits, as laid off workers can receive these benefits only after collecting all severance payments (on a monthly basis).

The changes to the unemployment scheme distort incentives of the unemployed and firms to search for and create jobs. First, the higher replacement rates reduce the job search of the unemployed and their willingness to accept lower wages. Second, the rule that benefits can be collected only at the end of the severance notice period "penalizes" workers for finding jobs early, by making them forego a larger portion of the benefit entitlements. Finally, as employers contribute more to the Unemployment Insurance Fund to

17. The Act will make Estonia's EPL score comparable to those of the Central European countries.

18. European countries adopted two major labour market strategies: $i$ ) partial reforms of short-term contract regulations only; and ii) moderately loose regulations of permanent contracts accompanied by generous unemployment benefits and effective active labour market policies.

19. The Act also improves employment prospects for young workers with lack of experience or skills and dampens incentives to create dual labour markets.

20. The replacement rate is $70 \%$ of the average salary during the first 100 days and $50 \%$ afterwards. As a response to the global crisis, several OECD countries extending the coverage (Sweden) or duration of their unemployment benefits (Portugal, United States). 
cover the higher benefits, they create fewer jobs, which amplifies the cycle. ${ }^{21}$ To counter the incentives stemming from more generous benefits, policy makers could strengthen the activation part of active labour market policies, especially on support for job search and increased placement services (see below).

\section{... and it supports life-long learning by granting study leaves}

The participation of adult working population in training increased in 2008. However, the incentives behind the learning programmes seem to exacerbate existing inequalities, with low-skilled workers participating less than the more educated ones (Table 5; OECD, 2005).

Table 5. Participation in life-long learning, by education attainment

In \% of relevant population ages $25-64$

\begin{tabular}{lcccccccc}
\hline & 2001 & 2002 & 2003 & 2004 & 2005 & 2006 & 2007 & 2008 \\
\cline { 2 - 9 } Total & 5.3 & 5.4 & 6.7 & 6.5 & 5.9 & 6.5 & 7 & 9.8 \\
< upper secondary & 1.1 & 0.6 & 1.2 & 1.1 & 1.3 & 1.5 & 1.6 & 2.1 \\
upper secondary & 3.8 & 4.6 & 4.8 & 4.8 & 4.7 & 4.9 & 5.5 & 7.5 \\
tertiary & 10.0 & 8.7 & 12.3 & 11.4 & 9.6 & 11.0 & 11.3 & 15.9 \\
\hline
\end{tabular}

Source: Statistics Estonia.

Even though the Act supports life-long learning by granting employees the time for study leave for up to 30 days a year, the employers or workers are responsible for financing such programmes. To encourage workers' life-time employability and adaptability to changing labour market conditions, the government could step up further support for life-long learning.

\section{Some measures to ease integration of foreign workers were also adopted}

In 2007, Estonia already was a net immigration country, underscoring the importance of creating an environment that would enable foreign workers to integrate effectively. Some progress towards this goal was already made in 2008, when parliament simplified procedures for employing non-EU migrant workers and raised, albeit marginally, the annual immigration quota (from $0.05 \%$ to $0.1 \%$ of the population). Moreover, the government's right to exclude certain groups of immigrants from the quota was abolished (Nurmela, 2008). ${ }^{22}$ The recent reforms notwithstanding, the overall policies pertaining to non-EU foreign workers are considered restrictive. Estonia could draw on good practices of other countries, including additional streamlining of the work permit process and a green card system, as was recently done in the Czech Republic. Establishing qualification recognition schemes would help attract skilled foreign workers. In addition, basic skills and language training could be further developed to help non-EU migrants better integrate into the labour market.

21. High unemployment benefits are associated with increased unemployment rate and duration (OECD, 2006; Vodopivec, Wörgötter and Raju, 2005). The length of the benefits also matters, as the unemployed intensify their job search about 1 month before their entitlements end (OECD, 2005a).

22. To attract skilled labour, the recent legislation set the minimum wage for migrant workers in 2008 at 13962 Kroons, or about triple of the minimum wage for the Estonian workers. 


\section{...But other key labour market institutions remain unchanged ${ }^{23}$}

- Estonia's expenditures on active labour market policies (ALMPs) as a share of GDP continue to be the lowest in the EU and well below OECD averages (Table 6). The ALMPs thus play only a minimal role in easing workers' exit from unemployment. Over the medium term, well designed increases in ALMPs would enhance workers' employability and give a larger role to automatic stabilizers (see below).

Table 6. ALMP expenditures in Estonia and several OECD areas

$\%$ of GDP in 2006

\begin{tabular}{lcccc}
\hline \multicolumn{1}{c}{ Programme category } & Estonia & $\begin{array}{c}\text { Nordic } \\
\text { countries }\end{array}$ & \begin{tabular}{c} 
Other OECD $_{\text {Europe }^{1}}$ \\
\cline { 2 - 5 } Active measures
\end{tabular} & $\begin{array}{c}\text { OECD } \\
\text { non-Europe }\end{array}$ \\
Of which: & & 1.17 & 0.66 & 0.27 \\
PES and administration & 0.05 & 0.22 & 0.19 & 0.13 \\
$\quad$ Training & 0.03 & 0.37 & 0.18 & 0.07 \\
Passive measures & 0.02 & 1.45 & 1.02 & 0.39 \\
TOTAL & 0.13 & 2.62 & 1.68 & 0.66 \\
\hline
\end{tabular}

1. Except Ireland.

Source: Grubb, Singh and Tergeist (2009) and the Estonian Ministry of Social Affairs.

- Involvement of the unions in wage setting is among the lowest in the EU and central Europe. Still, the unions negotiate wages in the public sector, large industrial enterprises, and the nation-wide minimum wage. Due to labour and skill shortages, collectively agreed public sector wage increases, adjusted for inflation, were among the highest in the EU and also exceeded labour productivity growth in 2006 and 2007. Increases in public sector wages should be kept in line with private sector productivity growth.

- While the level of the minimum wage is low (only $32 \%$ of the average wage in 2007), the recent real minimum wage increases exceeded both the EU average and productivity growth, thus "pricing out of jobs" low-wage workers for whom the minimum wage is binding. Increases of minimum wages should also be limited to private sector productivity growth. Negotiations could consider recommendations of an expert committee (see below).

- At almost $40 \%$ of labour costs the tax wedge was close to the EU15 average in 2006, as was the tax wedge for low-wage earners. The relatively high tax on labour is a key factor behind undeclared work (Leetmaa and Vork, 2007). Budgetary space should be created to lower the employers' social security contributions, especially on low-income workers (see below).

\section{Making labour market institutions more flexible}

Given the current downturn and the overexpansion of non-tradable sectors, in particular construction, a pressing issue for policymakers is how to facilitate reallocation of workers across jobs, sectors and regions to more productive activities, while considering the social and fiscal costs. With the low synchronization of Estonia's business cycles with those of the euro area, labour market flexibility is also a key adjustment mechanism to asymmetric shocks (OECD, 2009).

23. The existing (as of April 2009) labour market institutions are detailed in Annex. 


\section{Drawing on experiences of OECD countries}

Studies of labour market reforms in OECD countries emphasize reform complementarities and well-designed incentive structures (Elmeskov, Martin and Scarpetta, 1998). The 2006 reassessment of the Job Strategy identified two policy packages that worked: $i$ ) focusing product and labour market flexibility, even if income inequalities emerge (Australia, Canada, Japan, Korea, New Zealand, Switzerland, the United Kingdom and the United States); and ii) combining flexibility with security, with more equitable outcomes, but at higher cost (Austria, Denmark, Ireland, the Netherlands, Norway and Sweden). All successful reformers deregulated their product markets and maintained macroeconomic stability. Most also supported job search (OECD, 2006). The changes in the Act, in particular the reduced employment protection/increased unemployment benefit, suggest that Estonia strives to move towards the "flexibility with security" group. However, a significant ALMP component typical for this group is missing in the Estonian institutional landscape.

\section{EPL reform and severance payments}

Since the EPL reform was just adopted, further changes in the near future are unlikely. Still, Estonia could consider introducing an Austrian type savings scheme over the medium term, to further ease workers' movement across employers and reconcile flexibility with security. By replacing severance payments with transferable savings accounts, this scheme removes obstacles to workers' mobility between different employers, although at the cost of a slightly higher tax wedge (Box 2).

\section{Box 2. Austria's 2002 EPL reform}

The 2002 Austrian Severance Act shifts from a conventional system of severance payments to a system of individual saving accounts. Under the Austrian system, employers contribute $1.54 \%$ of the payroll bill to workers' individual accounts, from the first days of employment until the termination. If dismissed, workers with at least three years of tenure can receive severance payment drawn from their account (same rules as under the previous scheme apply) or take the accumulated balance to their next employer. The workers who are dismissed during their first three years on the job or quit voluntarily can also leave the accumulated balance in the account. The separation allowance can be accumulated by the employee over the entire working life.

From the employers' perspective, the system reduces the marginal cost of firing and the uncertainty related to this cost at the time of hiring. While the overall labour costs increase by the amount of the contribution, they will not pose liquidity concerns in the event of job termination. Moreover, under the traditional severance pay system, the layoffs tended to jump prior to employment tenure associated with increases in claims on severance payments, which would no longer be the case under the new system. The new system also eliminates incentives to lay-off workers in low-skilled jobs early on to avoid accumulation of severance payment claims not matched by productivity.

From the employee's perspective, the reform replaces the worker's security based on employment relationship between one worker and one employer with an employee benefit provision fund operated at the national level. Moreover, the new system extends the entitlement to severance payment, as it: i) starts after one month; ii) is independent of the way the contract is terminated; and iii) the severance claim increases progressively with time.

Source: OECD (2006). 


\section{Active labour market policies}

Well designed and targeted activation policies can offset the disincentives due to a generous unemployment benefits. Among various activation approaches, job search assistance or "work first" strategies tend to have a large impact and low cost (OECD, 2005a) ${ }^{24}$ Long-term labour market programmes alone, such as training, often have no or even a negative impact in the short term, but increase employment and earnings 2-3 years after the individuals completed them. Mixed strategies combining job search and selective training programme participation seem to be most effective.

Based on experiences of OECD countries, Estonia would improve effectiveness of its ALMPs at a given level of expenditures by linking increases in unemployment benefits to participation in ALMP programmes and monitoring performance of the employment offices. Increases of unemployment benefits and duration should be conditional on work availability and active job search (OECD, 2006). To raise ALMP's effectiveness, efficiency of employment services could also increase. Regarding benefit conditionality, Estonia could introduce practices of some of the OECD members:

- Required frequency of reporting of search activities could be raised from monthly to every two weeks, as is done, for example, in Australia, the Czech Republic, United Kingdom, and the United States. Personal visits seem most effective (OECD, 2007).

- Increases in benefit entitlements should be conditional on participation in ALMPs programmes, such as job creation. Similar links have been established in Australia (Mutual obligation strategy); the UK (New Deal strategy) and other European countries (Grubb, Singh and Tergeist, 2009).

\section{Life-long learning}

Technological progress in OECD countries over the past two decades has exhibited a bias against unskilled labour in favour of skilled labour (OECD, 2004). Improved training and life-long learning programmes help workers upgrade skills to stay up to date with these changes. Empirical evidence shows that, other things equal, workers who receive training have a greater chance of staying employed than their non-trained counterparts and have better re-employment opportunities in case of unemployment. Based on the experience of OECD countries, the government should step up its support for life-long learning, especially in areas where it would fill unmet labour market needs. ${ }^{25}$

\section{Measures affecting especially low-wage workers}

High tax wedges are particularly detrimental to employment in countries with high minimum wages, as the tax burden cannot be passed on to workers (Bassanini and Duval, 2006). In the Estonian context this provides additional reason (besides macroeconomic and inflationary considerations) why minimum wage increases should be kept in line with productivity growth and at a level which does not reduce employment options of low-productivity workers. Estonia could include an independent committee of outside experts in negotiations, also to bring the macroeconomic perspective, as was done, for example, in Ireland, the United Kingdom, and Australia. In addition, the employers' social security contribution should be reduced, especially given the high tax wedge on low-income workers, as was recently done, for example in the Czech Republic in the context of the economic crisis.

24. Through the "loss of leisure" element, job search programmes also ensure that benefits are provided to those who need them the most. However, this element of the activation programs should be set at a moderate level, i.e. it should not be equivalent to blank denial of the benefits (OECD, 2005a).

25. In the current crisis, the OECD countries are advised to provide job search assistance to the most employable unemployed, while also placing a greater reliance on training. Targeted hiring could be used for the most hard-to-place unemployed (Gurria, 2009). 


\section{Utilizing results of theoretical and empirical research}

A matching model with job search participation by the unemployed

Above sections propose several reforms that would make the Estonian labour market more flexible. To illustrate the likely medium-term outcomes of reforming the labour market institutions, changes in active labour market programmes (ALMPs), unemployment benefits, minimum wages, and employers' social security contributions are formally examined in a standard search model, applied to Estonia. Specifically, the model outlined below is a somewhat modified version of Van Ours (2007), which extends the search-matching framework of Mortensen and Pissarides (1999) by adding participation in job search programmes. The application below focuses on the effect of the labour reforms on incentives for the unemployed to search for jobs and for firms to create them.

In the model, workers can be either employed in the private sector or unemployed. Unemployed workers receive benefits $b$, value their leisure as $l$, and search for jobs with intensity $x \geq 0$ while incurring cost $k(x)=\frac{x^{2}}{2 \gamma}$, where $\gamma>0$. Employed workers receive wage $w$. Firms post vacancies to fill jobs at cost $c$. Each filled job results in output $y$, with $y>w$. The key component of the model is a matching function $A=A(x u)^{1-\eta} v^{\eta}$, where $A>0$ denotes the efficiency of the matching and $\eta \in(0,1)$ is the elasticity of matches with respect to vacancies. The workers' search results in job offers, which arrive at rate $\mu(\theta) x=A \theta^{\eta}$, where $\theta=\frac{v}{x u}$ denotes the ratio of vacancy rate, $v$, to unemployment rate, $u$, i.e. it describes the tightness of the labour market from firms' perspective. Conversely, firms fill their vacancies at rate $\frac{\mu(\theta)}{\theta}=A \theta^{\eta-1}$. All job matches dissolve at rate $\delta$, and firms pay to each laid-off worker a severance payment $K$. The employment rate, $e$, and unemployment rate, $u$, change according to:

$$
\begin{aligned}
& \dot{e}=A \theta^{\eta-1} v-\delta e \\
& \dot{u}=\delta e-A \theta^{\eta} x u
\end{aligned}
$$

With normalizing the labour force to 1 , that is $1=e+u$, the steady state equilibrium unemployment decreases with search effort and tightness of the labour market:

$$
\bar{u}=\frac{\delta}{\delta+A \bar{\theta}^{\eta} \bar{x}}
$$

To illustrate the impact of mandatory participation in ALMPs on workers' search, a scenario where all unemployed workers can receive unemployment benefit only if they participate in the job search assistance programme is considered. Participation in such programme lowers the value of leisure for the unemployed by fraction $z \in(0,1)$ and their search cost by a fraction $\sigma \in(0,1)$. Workers accept jobs only when the value of employment, $V_{E}$, exceeds the value on unemployment, $V_{U}$ :

$$
\rho V_{U}=\max _{x}\left(b+(1-z) l-\frac{(1-\sigma) x^{2}}{2 \gamma}+A \theta^{\eta} x\left(V_{E}-V_{U}\right)\right)
$$




$$
\rho V_{E}=w+\delta\left(V_{U}-V_{E}\right)
$$

where $\rho$ is the discount rate. Denoting $J_{E}$ as value of filled job and $J_{V}$ as value of vacancy, the corresponding Bellman equations are:

$$
\begin{aligned}
& \rho J_{E}=y-(1+\tau) w+\delta\left(J_{V}-J_{E}-K\right) \\
& \rho J_{V}=-c+A \theta^{\eta-1}\left(J_{E}-J_{V}\right)
\end{aligned}
$$

Where $y$ is the output from the filled vacancy, $w \tau$ is the social employers' contribution tax paid, and $K$ is the severance cost incurred by the firm. Under the standard assumption of free entry into the job-creation, value of posting a vacancy is $J_{v}=0$. (6) and (7) can therefore be reduced to:

$$
\frac{y-(1+\tau) w-\delta K}{\rho+\delta}=\frac{c \theta^{1-\eta}}{A}
$$

The optimal search intensity $x$ can be derived directly from (4):

$$
\bar{x}=\frac{\gamma}{(1-\sigma)} A \theta^{\eta}\left(V_{E}-V_{U}\right)
$$

The search effort increases with higher loss of leisure due to participation in the search programme as well as with lower search costs.

To complete characterization of unemployment outlined in (3), solution for the tightness of the labour market, $\theta$, needs to be obtained through deriving wages. Regarding wage determination, the model deviates from the standard assumption of Nash wage bargaining. Instead, it assumes that flexible wages move productivity changes: $w=\phi y$, where $\phi \in(0,1)$, consistently with the empirical evidence (Babecky, 2007; and Room, 2008).

\section{Comparative statics}

The solution for the steady state search effort and unemployment rate can be derived from (1)-(4) and $\left(1^{\prime}-5\right.$ ') in Annex II. The comparative statics relevant in the Estonian context are:

Table 7. Comparative statics in the job search-matching model

\begin{tabular}{lcc}
\hline Effect of an increase in: & $\begin{array}{r}\text { On search effort of the } \\
\text { unemployed } x\end{array}$ & $\begin{array}{c}\text { On unemployment } \\
\text { rate } u\end{array}$ \\
\cline { 2 - 3 } Reduced utility from less leisure $z$ & + & - \\
Search cost reduction $\sigma$ & + & - \\
Matching efficiency $A$ & + & + \\
Minimum wage $w^{\text {min }}>\phi y$ & + & + \\
Unemployment benefit $b$ & - & + \\
Payroll tax $\tau$ & - & +
\end{tabular}


The search of the unemployed increases with effective job search programmes, lower search cost, improved matching efficiency, and reduced separation rate. The ALMPs could improve matching efficiency (by dissemination of information) as well as reduce search cost and separation rate.

\section{Simulations}

The model is simulated using quarterly parameters from existing studies and the Estonian labour market data. Parameters are specified as follows:

Table 8. Parameters of the model

\begin{tabular}{|c|c|c|c|}
\hline Parameter & Definition & Value & Source \\
\hline$y$ & Output (productivity) & 1 & Van Ours (2007) \\
\hline$\delta$ & Separation rate (quarterly) & 0.045 & Statistics Estonia \\
\hline$\tau$ & $\begin{array}{l}\text { Social security contribution } \\
\text { (\% of wage) }\end{array}$ & 0.33 & Ministry of Finance, the Republic of Estonia \\
\hline$c$ & Cost of posting vacancies & 6 & $\begin{array}{l}\text { Set so that vacancy-unemployment ratio corresponds to } \\
\text { the steady state value of } 0.8 \text { (based on past outcomes) }\end{array}$ \\
\hline$\eta$ & $\begin{array}{l}\text { Elasticity of matching to } \\
\text { Vacancies }\end{array}$ & 0.5 & Van Ours (2007) \\
\hline$\rho$ & Discount rate & 0.025 & Van Ours (2007) \\
\hline A & $\begin{array}{l}\text { Efficiency of matching } \\
\text { Function }\end{array}$ & 1 & Van Ours (2007) \\
\hline b & $\begin{array}{l}\text { Unemployment benefit, } \\
\text { Including value of leisure }\end{array}$ & 0.4 & Shimer (2005) \\
\hline$b_{u}$ & Replacement rate (part of b) & 0.25 & Set at the current rate of $50 \%$ \\
\hline$\gamma$ & Cost of job search & 0.9 & Set to obtain steady state unemployment of $6.5 \%$ \\
\hline$\phi$ & Share of wage in output & 0.5 & Share of compensation of employees in GDP \\
\hline
\end{tabular}

Figures 9 and 10 illustrate that compulsory participation in active labour market programme, especially job search activation programmes, would increase workers search efforts through two channels: 1) by reducing the value of leisure and hence increasing relative payoffs from working; and 2) by reducing the workers'cost of search through training, and dissemination of information. As a result of workers' increased search, unemployment would decline in both cases.

Figure 9. Impact of mandatory participation in labour market policies on search and unemployment

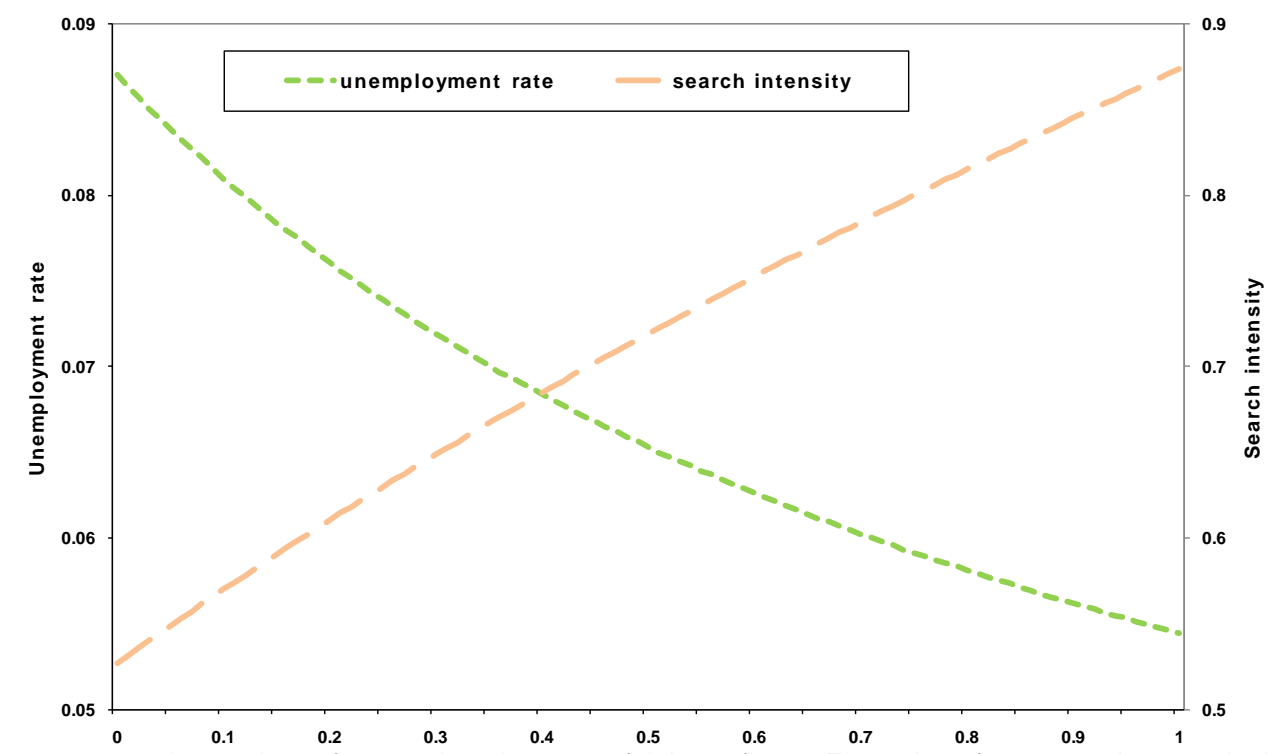

Note: Unemployment rate is number of unemployed as \% of labour force. For units of consumption good, the price of the consumption good is normalised to one. Mandatory participation represents foregone leisure. 
Figure 10. Impact of search cost cuts on search and unemployment

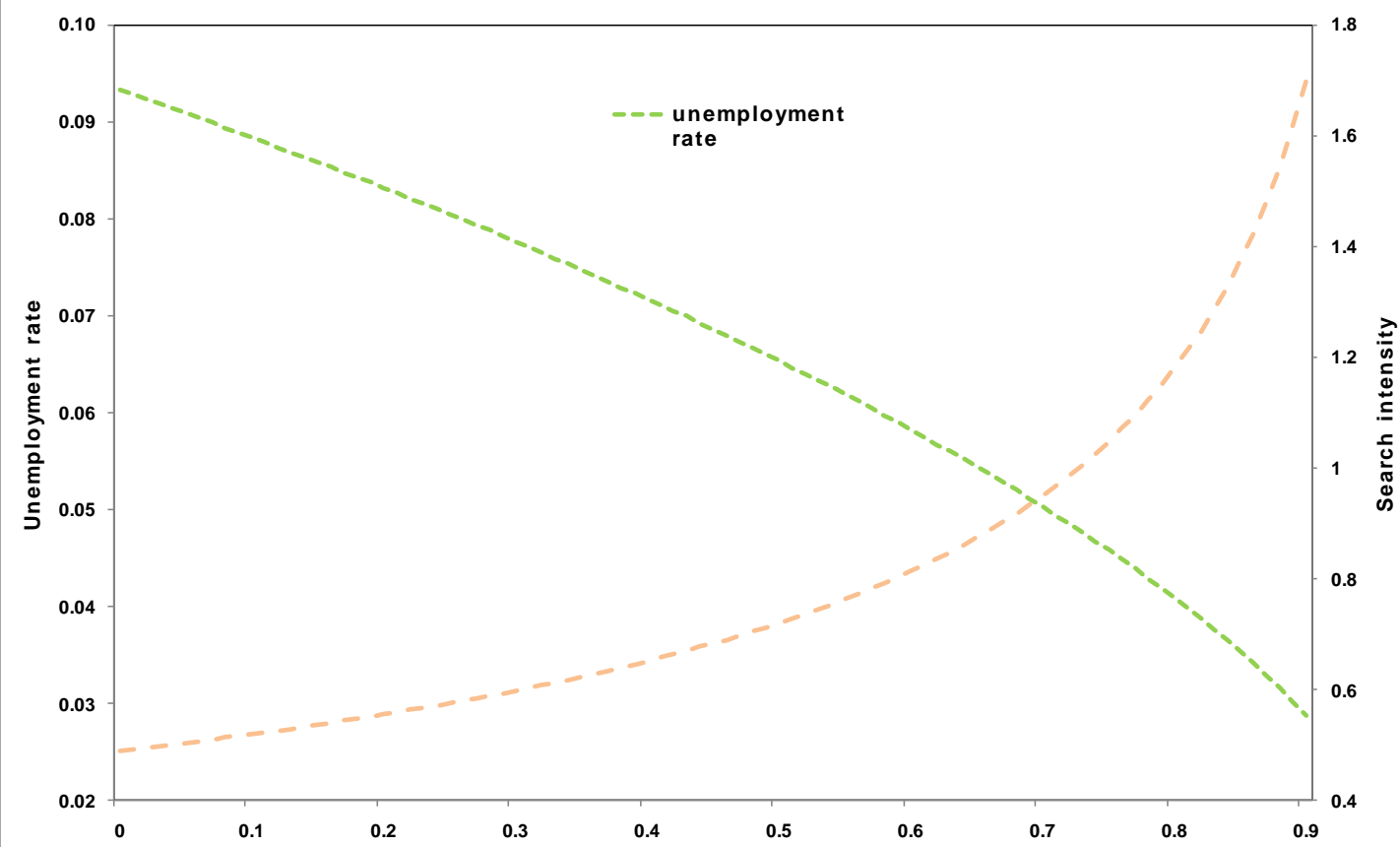

Note: Unemployment rate is number of unemployed as \% of labour force. For units of consumption good, the price of the consumption good is normalised to one.

Source: Author's calculations.

Figure 11. Impact of minimum wage increase on search, unemployment and vacancies

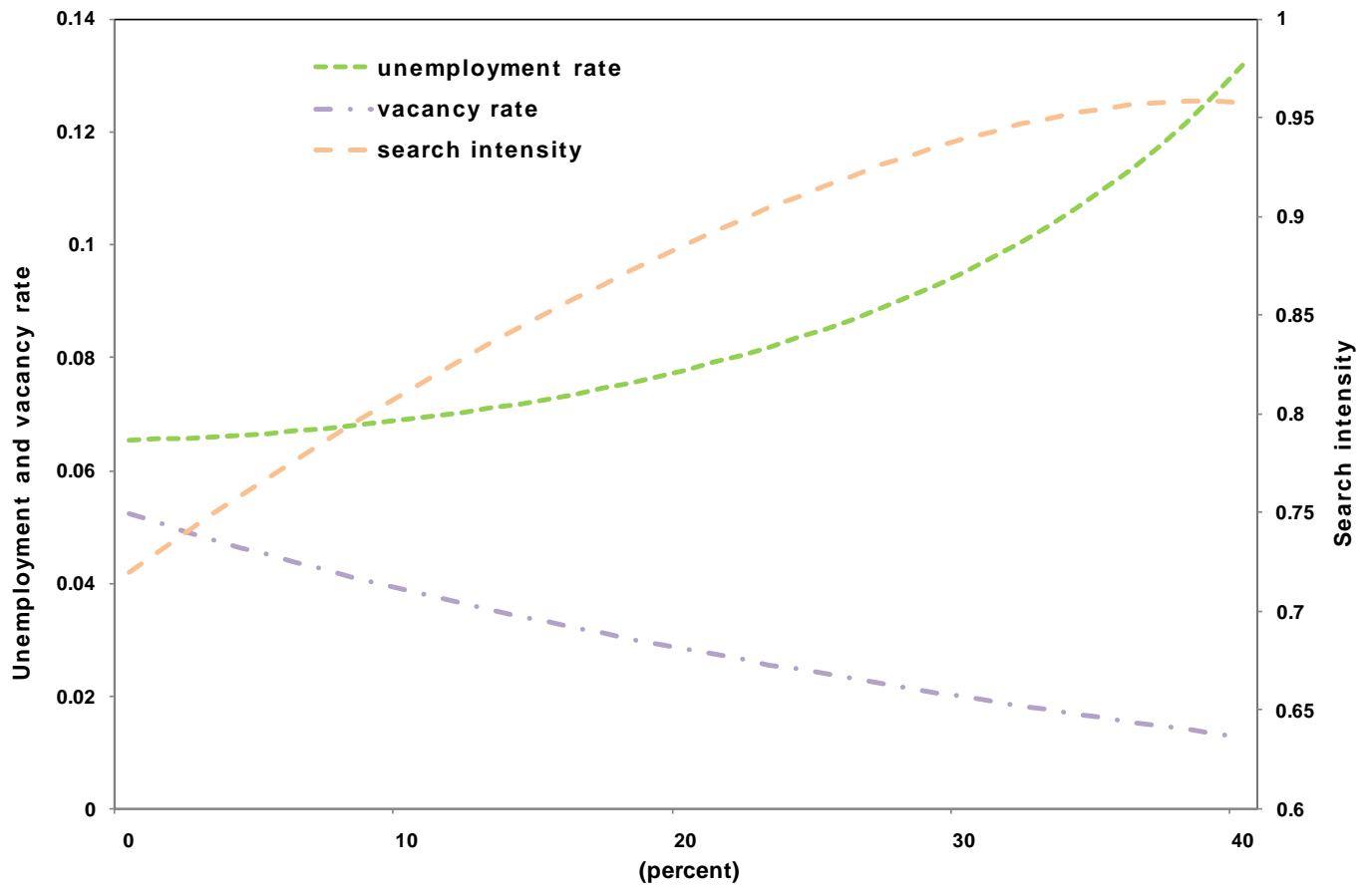

Note: Unemployment and vacancy rates are respectively the number of unemployed and vacancies as \% of labour force. For units of consumption good, the price of the consumption good is normalised to one.

Source: Author's calculations. 
Figure 12. Impact of social security tax on vacancies and unemployment

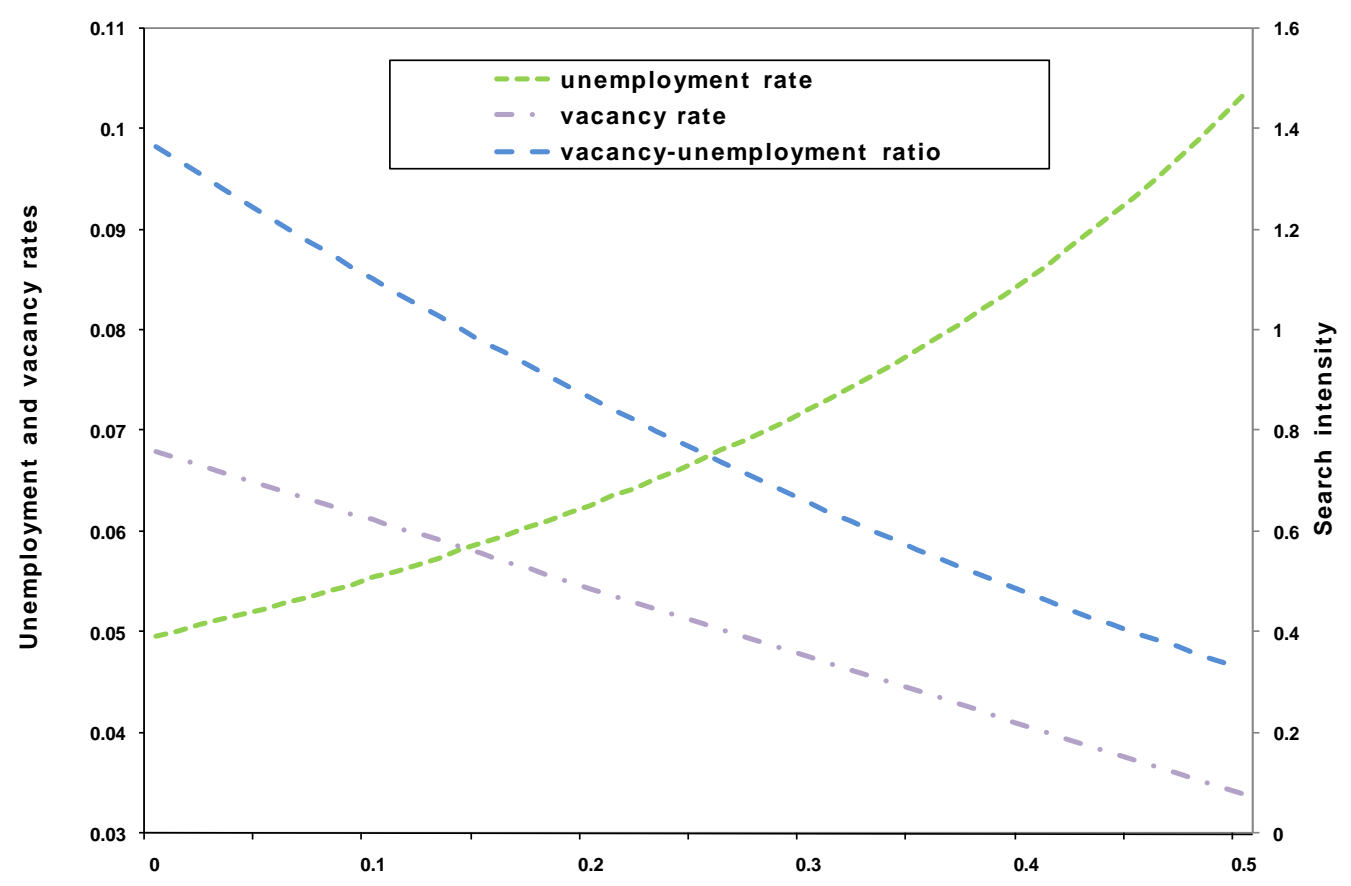

Note: Unemployment and vacancy rates are respectively the number of unemployed and vacancies as \% of labour force. The vacancy/unemployment ratio is the vacancy rate divided by the unemployment rate.

Source: Author's calculations.

Figure 11 illustrates how impact of increases in minimum wages on the low-wage unemployed workers for whom they may be a binding constraint. While workers would increase their search effort because of a higher payoff from working, the positive impact would be more than offset by firms' posting fewer vacancies because of lower profits. Figure 12 illustrates the likely impact of cuts in social contribution tax paid by employers. The direct consequence would be a higher profitability of firms and hence more vacancies/lower unemployment rate, provided that the lost revenues are replaced by less distortionary taxes.

Policy lessons

More generous unemployment benefits reduce workers' incentives to search by making employment relatively less attractive option. Since the new Act delays the start date of collecting the unemployment benefits until workers receive all severance payments, serious search efforts are postponed, with negative implications for the steady state unemployment level and duration. These impacts could be offset by:

- Linking increases in unemployment benefits to participation in job search programmes would improve workers' incentives to search for jobs, by reducing both the value of being unemployed and search costs.

- While lower minimum wages would somewhat hamper incentives of the low-wage unemployed to search for jobs, firms would be more willing to hire. The unemployment rate would decline as long as the current minimum wage level is found to be binding.

- A lower tax wedge due to cuts in firms' social security contributions would raise firms' payoff from filled jobs, and hence their incentives to post vacancies. Search effort of workers would also 
increase, as their chances of finding jobs would improve. Both the unemployment level and duration would decline.

\section{Empirical research on the speed of adjustment and transition costs}

Although the results presented in the previous section focus on the longer-term outcomes, the above measures would also affect the speed of adjustment and the associated transition costs, and hence the political support for the reforms.

Mourougane and Vogel (2008) examined the length of adjustments to selected structural reforms in the OECD countries and found that the impact of structural reforms spreads out over several years. As reallocation of resources is costly, the efficiency gains take time to materialize. Effective monetary policy and well-functioning financial markets can reduce the adjustment speed and transition cost. According to the authors, tax wedge, unemployment replacement ratio, and product market regulations play a major role in explaining the evolution of structural unemployment in OECD countries during 1983-2003. Tax wedge and product market regulations have also the largest impact in the short run. This research confirms the importance of reducing social security tax, especially on low income workers, as way to ease the recovery and reduce medium-term unemployment.

Analyzing the effects of changes in the EPL, Caballero et al. (2004) found that in countries with a strong law enforcement, increasing job security would reduce the annual speed of adjustment to shocks by a third, while subtracting $1 \%$ from productivity growth. This work also underscores the importance of deregulating the EPL, as stipulated in the Act.

\section{Summary}

Estonia's labour market is already flexible in many aspects, but evidence points to rigidities and inequalities in several areas. Drawing on experiences of OECD countries as well as results of theoretical and empirical research, Box 3 summarizes policy recommendations that would increase flexibility of the Estonia's labour market. Such measures would improve medium-term outcomes and ease the recovery, while reducing some of the inequalities.

\section{Box 3. Policy recommendations for increasing flexibility of the labour market}

\section{Strengthen incentives for job search and job creation.}

- Reducing lay-off notice periods and severance payments as stipulated in the newly adopted Employment Act is a welcome step. Implement the EPL changes fully as stipulated in the Act.

- $\quad$ Over the medium term, consider replacing severance payment with an Austrian type savings scheme to facilitate mobility across employers.

- Given that the new Employment Act increased unemployment benefits and de facto prolonged their duration, make benefit increases conditional on participation in active job search. Impose sanctions for non-compliance.

- $\quad$ Reduce tax wedge by reducing social contribution paid by employers, especially on low-wage workers.

- Keep increases in public sector wages in line with private sector productivity growth.

Reduce employment disincentives for low-wage workers 
- Keep rises of minimum wages in line with productivity. Reduce politicisation of decisions on minimum wage increases by bringing outside expertise into the negotiations between trade unions and employers' confederation.

\section{Encourage life-time employability}

- $\quad$ Encourage further life-long learning and skill upgrading.

- Over the medium term, well designed and implemented increases in ALMPs could be considered, given their currently very low level.

Facilitate labour market integration of ethnic non-Estonians and foreign migrants

- Increase access of these groups to the Estonian language and professional training.

- $\quad$ Simplify further the work permit process for non-EU foreign workers (along the lines of the Czech Republic). Establish a system of formal recognition of migrants' qualifications. 
ECO/WKP(2009)38

\section{BIBLIOGRAPHY}

Babecky, J. (2008), "Aggregate wage flexibility in the new EU member States", AUCO Czech Economic Review 2, Vol. 2, pp. 123-145.

Bank of Estonia (2008), "Institutional developments of the labour market", Labour Market Review, Vol. 1, pp. 30-33.

Bassanini, A. and R. Duval (2006), "Employment patterns in OECD countries: reassessing the role of policies and institutions, Social, Employment and Migration Working Papers, No. 35, OECD, Paris.

Brixiova, Z., W. Li and T. Yousef (2009), "Skill shortages and labour market outcomes in Central Europe", Economic Systems, Vol. 33, Issue 1, pp. 45-59.

Caballero et al. (2004), "Effective labour regulation and microeconomic flexibility", Federal Reserve Bank of Boston Working Papers, No. 04-06.

Dabusinskas, A. and T. Room (2008), "New survey evidence on wage and price formation by Estonian firms: A first look at the data", presentation at the Bank of Estonia, 24 January 2008.

Eamets, R. and T. Paas (2007), "Labour market flexibility and flexicurity", in Paas and Eamets (eds.), Labour Market Flexibility, Flexicurity, and Employment: Lessons of the Baltic States, pp. 41-60.

Eamets, R. and J. Masso, (2005), "Paradox of the Baltic States: labour market flexibility but protected workers?", European Journal of Industrial Relations, Vol. 11, No. 1, pp. 71-90.

Elmeskov, J., J.P. Martin, and S. Scarpetta (1998), "Key lessons for labour market reforms: evidence from OECD countries' experiences”, Swedish Economic Policy Review, Vol. 5, pp. 205-252.

European Commission (2008), Employment in Europe, European Commissions, Brussels.

Gurria, A. (2009), People first: Tackling together the human dimension of the crisis, speech delivered at the G8 Labour Ministerial Social summit 2009.

Grubb, D., S. Singh and P. Tergeist (2009), “Activation policies in Ireland”, OECD Social, Employment, and Migration Working Papers, No. 75.

Iara, A. et al. (2009), "Migration and community propensity in the new EU member states", The Vienna Institute for International Economic Studies Research Reports, 351.

Karu, M. and L. Roosaar (2006), "Trends in labour market participation, income and job satisfaction among non-nationals", Eurofound EWCO, September.

Kroncke Ch. and K. Smith (1999), “The wage effects of ethnicity in Estonia”, Economics of Transition, Vol. 7 (1), 179-99.

Leping, K-O. and O. Toomet, (2008), "Emerging ethnic wage gap: Estonia during political and economic transition", Journal of Comparative Economics, Vol. 36, pp. 599-619. 
Leetmaa, R. and A. Vork (2007), "Article on undeclared work from SYSDEM correspondent: Estonia”, European Employment Observatory, May.

Masso, J. and R. Eamets (2007), "Macro-level labour market flexibility in the Baltic states", in Paas and Eamets (eds.), Labour Market Flexibility, Flexicurity, and Employment: Lessons of the Baltic States, pp. 101-142.

Masso, J., R. Eamets, and K. Philips (2007), "Job flows and worker flows in the Baltic states: Labour reallocation and structural changes", in Paas and Eamets (eds.), Labour Market Flexibility, Flexicurity, and Employment: Lessons of the Baltic States, pp. 61-100.

Mortensen, D. and C. Pissarides (1999), "New developments in models of search in the labour market", in Ashenfelter, O. and D. Card (eds.), Handbook of Labour Economics, Vol. 3, pp. 2567-2627,

North-Holland, Amsterdam.

Mourougane, A. and L. Vogel (2008), "Speed of adjustment to selected labour market and tax reforms", OECD Economics Department Working Papers, No. 647.

Münz, R. (2008), "Migration, labour markets, and integration of migrants: an overview for Europe", World Bank Social Protection Discussion Papers, No. 807.

Nurmela, K. (2008), “Better provisions for non-EU migrant workers”, Eurofound EIROnline, April.

OECD (2009), OECD Economic Surveys - Estonia, OECD, Paris.

OECD (2007; 2006; 2005a; 2004), OECD Employment Outlook, various issues, OECD, Paris.

OECD, 2005b, Promoting Adult Learning, OECD, Paris.

Van Ours, J. (2007), "Compulsion in active labour market programmes", National Institute Economic Review, No. 202, pp. 67-78, October.

Pissarides, C. (1997), "The need for labour market flexibility in a European economic and monetary union", Swedish Economic Policy Review, No. 4, 513-546.

Room, T. (2008), “The principles of wage formation in Estonian companies”, Bank of Estonia, draft.

Shimer, R. (2005), "The cyclical behaviour of equilibrium unemployment and vacancies", American Economic Review, 95 pp. 24-49, March.

Statistics Estonia (2009), Migration 2000-07, Statistics Estonia, Tallinn.

Svejnar, J. (2003), "Labour market flexibility in Central and Eastern Europe“, in M. Dabrowski and B. Slay (eds.), Beyond Transition, M.E. Sharpe.

Vodopivec, M. (2000), "Worker reallocation during Estonia's transition to market: how efficient and how equitable?", World Bank Social Protection Discussion Papers, No. 18.

Vodopivec, M., A. Wörgötter and D. Raju (2005), "Unemployment benefit system in Central and Eastern Europe: a review of the 1990s", Comparative Economic Studies, Vol. 47, pp. 615-651. 
ECO/WKP(2009)38

\section{ANNEX. CURRENT LABOUR MARKET INSTITUTIONS IN ESTONIA ${ }^{1}$}

Unemployment benefit system consists of unemployment insurance and unemployment assistance. The initial replacement rates of the unemployment insurance are set at 50\% of previous income for the first 100 days and $40 \%$ afterwards. Depending on the length of contributions to the fund, the duration of benefits ranges from 180 to 360 days. After the insurance expires, the unemployed can apply for unemployment assistance benefits for another 90 days and social assistance afterwards, conditional on income. When combined with the maximum severance payment ( 3 months), workers could be on severance and unemployment benefits for up to 36 months after being laid off. ${ }^{2}$

Trade unions and collective bargaining. Union membership and collective agreement coverage are low in comparison with other EU countries, and the bargaining power of the unions weak. The coverage has been steadily declining since its peak in 1992 due to privatization and shift of the labour force from manufacturing (with strong unions) to services (with weak ones). Coordination is also weak, in particular in small and medium-sized enterprises. The unions play an important role in large industrial companies, including in textile, road and railway transport, and postal sector.

Wage setting. Given the low level of trade union membership, the wage setting is almost fully decentralized, with wages determined mostly within firms, with the exception of minimum wage (see below), wages in the civil service sector (set by government regulations) as well as wages in selected heavily unionized industries. According to Room (2008) wage adjustments are frequent, with substantial cyclical fluctuations and sectoral dispersion. While until 2004 wage increases reflected closely productivity gains, in recent years the real wage increases were above productivity due to labour and skill shortages.

Minimum wages are determined annually through agreement between trade unions and representatives of employers. According to Room (2008) and other estimates, currently approximately 6\% of private sector workers earn minimum wage. But in some unionized enterprises (textile), minimum wages constitute a basis from which wages of all workers are derived. Increase in the past years has been rapid - for over 20\% in 2007, 2008 vs. 9 and 12\% in 2005 and 2006, respectively.

Tax burden on labour. The Estonian labour costs are considered relatively high partly because of social contribution tax imposed on employers (33\% of wages, split into $13 \%$ for health insurance s and $20 \%$ for pension contributions). One of the proposals of the employers' representatives is to shift the burden of taxation from employers to workers, by splitting the contribution.

Compulsory job search in ALMPs. The compulsory element to search for jobs requires that the unemployed workers: $i$ ) contact the relevant labour market board at least once a month, either by phone or in person; ii) follow Individual Action Plan designed together with the board; iii) accept suitable employment (for the third time). If the unemployed do not comply with these requirements, they would lose their registration as unemployed and hence entitlement to unemployment benefits.

1. As of April 2009.

2. In 2007 only about $20 \%$ of the registered unemployed received unemployment insurance benefits and about $45 \%$ unemployment assistance benefits. Unemployment has been identified as one of the main risks for poverty. 


\section{WORKING PAPERS}

The full series of Economics Department Working Papers can be consulted at www.oecd.org/eco/working_papers/

696. Structural policies to overcome geographic barriers and create prosperity in New Zealand (April 2009) Yvan Guillemette

695. Ten years of product market reform in OECD countries - insights from a revised PMR indicator (April 2009) Anita Wölfl, Isabelle Wanner, Tomasz Kozluk and Giuseppe Nicoletti

694. Structural reforms and the benefits of the enlarged eu internal market (April 2009) Jens Arnold, Peter Höller, Margaret Morgan and Andreas Wörgötter

693. Co-benefits of climate change mitigation policies: literature review and new results (April 2009) Johannes Bollen, Bruno Guay, Stéphanie Jamet and Jan Corfee-Morlot

692. The impact of monetary and commodity fundamentals, macro news and central bank communication on the exchange rate: Evidence from South Africa (April 2009) Balázs Égert

691. Assessing the impacts of climate change: a literature review (April 2009) Stéphanie Jamet and Jan Corfee-Morlot

690. The determinants of employment and earnings in Indonesia: a multinomial selection approach (April 2009) Margherita Comola and Luiz de Mello

689. Inflation responses to recent shocks: do G7 countries behave differently (April 2009) Lukas Vogel, Elena Rusticelli, Pete Richardson, Stéphanie Guichard and Christian Gianella

688. Infrastructure investment in network industries: the role of incentive regulation and regulatory independence

(March 2009) Balázs Égert

687. Government consumption volatility and the size of nations

(March 2009) Davide Furceri and Marcos Poplawski Ribeiro

686. Infrastructure investment: links to growth and the role of public policies (March 2009) Balázs Égert and Tomasz Kozluk and Douglas Sutherland

685. Infrastructure and growth: empirical evidence

(March 2009) Balázs Égert and Tomasz Kozluk and Douglas Sutherland

684. The effects of population structure on employment and productivity (March 2009) Hervé Boulhol

683. The macroeconomic consequences of banking crises in OECD countries (March 2009) David Haugh, Patrice Ollivaud and David Turner 
682. Adjusting housing policies in Slovakia in light of euro adoption (March 2009) Felix Hüfner

681. Achieving fiscal flexibility and safeguarding sustainabilit - The case of Slovakia (March 2009) Isabell Koske

680. Raising the flexibility of the Slovak economy during the catch-up phaseDo Latin American central bankers behave non-linearly? The experience of Brazil, Chile, Colombia and Mexico (March 2009) Isabell Koske

679. Do Latin American central bankers behave non-linearly? The experience of Brazil, Chile, Colombia and Mexico

(February 2009) Luiz de Mello, Diego Moccero and Matteo Mogliani

678. Enhancing educational performance in Australia

(February 2009) Vassiliki Koutsogeorgopoulou

677. Quantifying the effect of financial conditions in the euro area, Japan, United Kingdom and United States

(February 2009) Stéphanie Guichard, David Haugh et David Turner

676. Taking stock of existing structural policy and outcome indicators/ Un inventaire des indicateurs structurels de politique et de performance

(February 2009) Davide Furceri and Annabelle Mourougane

675. Stabilization Effects of Social Spending: Empirical Evidence from a Panel of OECD Countries (February 2009) Davide Furceri

674. Fiscal Convergence, Business Cycle Volatility and Growth (February 2009) Davide Furceri

673. Boosting Productivity in Korea's service sector (February 2009) Randall S. Jones

672. Sustaining growth in Korea by reforming the labour market and improving the education system (February 2009) Randall S. Jones and Masahiko Tsutsumi

671. Reforming the tax system to promote economic growth and cope with rapid population ageing (February 2009) Randall S. Jones

670. Financial market stability: Enhancing regulation and supervision (February 2009) Jeremy Lawson, Sebastian Barnes and Marte Sollie

669. Overcoming the financial crisis (February 2009) Andrea De Michelis

668. Financial crises: past lessons and policy implications (February 2009) Davide Furceri and Annabelle Mourougane

667. Reforms to open sheltered sectors to competition in Switzerland (February 2009) Andrés Fuentes 